Macroeconomic and interest rate volatility under alternative monetary operating procedures

Petra Gerlach-Kristen and Barbara Rudolf

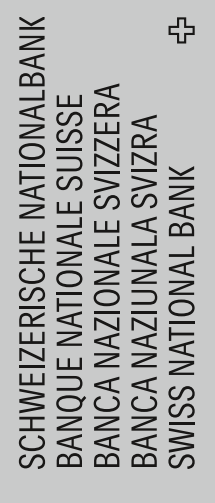


The views expressed in this paper are those of the author(s) and do not necessarily represent those of the Swiss National Bank. Working Papers describe research in progress. Their aim is to elicit comments and to further debate.

\section{Copyright $\odot$}

The Swiss National Bank (SNB) respects all third-party rights, in particular rights relating to works protected by copyright (information or data, wordings and depictions, to the extent that these are of an individual character). SNB publications containing a reference to a copyright ( $\odot$ Swiss National Bank/SNB, Zurich/year, or similar) may, under copyright law, only be used (reproduced, used via the internet, etc.) for non-commercial purposes and provided that the source is mentioned. Their use for commercial purposes is only permitted with the prior express consent of the SNB.

General information and data published without reference to a copyright may be used without mentioning the source.

To the extent that the information and data clearly derive from outside sources, the users of such information and data are obliged to respect any existing copyrights and to obtain the right of use from the relevant outside source themselves.

\section{Limitation of liability}

The SNB accepts no responsibility for any information it provides. Under no circumstances will it accept any liability for losses or damage which may result from the use of such information. This limitation of liability applies, in particular, to the topicality, accuracy, validity and availability of the information.

ISSN 1660-7716 (printed version)

ISSN 1660-7724 (online version)

๑ 2010 by Swiss National Bank, Börsenstrasse 15, P.0. Box, CH-8022 Zurich 


\title{
Macroeconomic and interest rate volatility under alternative monetary operating procedures
}

\author{
Petra Gerlach-Kristen \\ Bank for International Settlements
}

and

\author{
Barbara Rudolf* \\ Swiss National Bank
}

August 19, 2010

\begin{abstract}
During the financial crisis of 2007/08 the level and volatility of interest rate spreads increased dramatically. This paper examines how the choice of the target interest rate for monetary policy affects the volatility of inflation, the output gap and the yield curve. We consider three monetary policy operating procedures with different target interest rates: two market rates with maturities of one and three months, respectively, and an essentially riskless one-month repo rate. The implementation tool is the one-month repo rate for all three operating procedures. In a highly stylised model, we find that using a money market rate as a target rate generally yields lower variability of the macroeconomic variables. This holds under discretion as well as under commitment both in times of financial calm or turmoil. Whether the one month or three month rate procedure performs best depends on the maturity of the specific rate that enters the IS curve.
\end{abstract}

\footnotetext{
*petra.gerlach@bis.org and barbara.rudolf@snb.ch. The views expressed in this paper are the authors' and do not necessarily reflect those of the Bank for International Settlements or of the Swiss National Bank. We thank an anonymous referee, Andreas Fischer, Leonardo Gambacorta, Stefan Gerlach, Charles Goodhart, Alfred Guender, Sébastien Kraenzlin, Pierre Monnin, Michel Peytrignet, Angelo Ranaldo, Enzo Rossi, Marcel Savioz, Martin Schlegel, Paul Söderlind, Mathias Zurlinden and seminar participants at the BIS, the Bundesbank, the European Central Bank, Oxford University and the SNB for useful discussions.
} 


\section{Introduction}

Monetary policy operating procedures vary from one country to another. In particular, there are major differences regarding the target interest rate used to formulate monetary policy. Some central banks have as operational target a short-term market interest rate while others use the rate they charge financial institutions for the provision of short-term funds - typically a repo rate. Since short-term interest rates in a given currency tend to move closely in line with each other during normal times, these differences have attracted little attention in the literature. ${ }^{1}$ In the financial crisis of $2007 / 08$, however, the level and volatility of interest rate spreads increased dramatically, raising the issue of how alternative monetary policy procedures impact on the economy. In this paper, we examine how the choice of monetary operating procedure affects the volatilities of the inflation rate, the output gap and the term structure of market rates.

The model is standard in that it consists of a hybrid New Keynesian Phillips curve and a consumption Euler equation. The novelty is the consideration of three possible interest rates for monetary policy: a repo rate with a one-period maturity and two money market rates with maturities of one and three periods, respectively. Policy may be formulated with either of these rates as target rate, but is always implemented with the one-period repo rate. The market rates are modelled to depend on the expected future path of the repo rate, a term premium and a risk premium. Since risk premia are largely driven by markets' perception of default risk, we assume that these premia are linked to economic conditions and let them depend endogenously on the expected future path of the output gap. Following the literature, we let the one-month money market rate impact on the output gap in the IS curve in the baseline model, but we also consider a variant of the model where the average of short and longer-term money market rates matters.

We compare the three monetary operating procedures by examining optimal policy reaction functions, impulse responses and simulated volatilities of inflation, the output gap and the yield curve. This is done first for a baseline calibration, using parameters chosen to mirror pre-crisis conditions, and then for an alternative set of parameters which reflects the financial turmoil. Results are presented for both, policy under commitment and under discretion. We then consider how the results change if an average interest rate that is constructed from market rates of maturities lasting from one to twelve months matters for economic activity. Finally,

\footnotetext{
${ }^{1}$ Exceptions are Bindseil [5] and Borio [6]. Borio and Nelson [7] discuss monetary operations during the financial crisis.
} 
since there have been calls for using monetary policy to stabilise asset prices, we examine how an additional target for stabilising the yield curve impacts on volatilities under the three operating procedures.

The results suggest that under commitment, the three operating procedures give similar results in terms of macroeconomic volatility in tranquil times. Under discretion, market-based procedures yield a more stable macroeconomy. In times of financial turmoil, targeting the shortterm market interest rate is advantageous both under commitment and discretion. If we depart from the baseline model and assume that also longer-term market rates matter for the output gap, the different procedures yield equal volatility if policy is set under commitment. Under discretion, the approach where monetary policy is formulated it terms of a longer-term market rate seem most promising. Finally, if the central bank tries to stabilise the yield curve, for instance because too low a level of the term structure can give rise to asset price booms, our model shows a feedback effect that increases not only the volatility of inflation and the output gap, but also of the yield curve itself.

This paper adds to a growing literature that models the linkages between financial market interest rates, risk premia and the macroeconomy. Goodfriend and McCallum [20] assume an interbank policy interest rate, a risk-free rate, and collateralised and uncollateralised market rates in an economy with a banking sector and discuss the responses of these interest rates to shocks. Cúrdia and Woodford [9] model the spread between borrowing and lending rates and show that monetary policy provides better results if the central bank reacts to movements in the credit spread. The reason is that the rate relevant for economic activity is not the policy rate itself but an interest rate that depends on the credit spread. ${ }^{2}$ Eijffinger, Schaling and Verhagen [12], Fendel [17], Lansing and Trehan [27] and Svensson [37] present optimal policy rules for a short-term interest rate in models where a longer-term rate, which obeys the expectations hypothesis, matters for the output gap. Conversely, Kulish [26] and McGough, Rudebusch and Williams [30] let the shorter-term market rate enter the IS curve and analyse different reaction functions for the longer-term interest rate, which, however are not derived optimally. GerlachKristen and Rudolf [19], finally, compare the performance of Taylor rules for both a short and a longer-term interest rate when the latter matters for economic activity.

The paper is organised as follows. Section 2 gives a brief description of policy rates and

\footnotetext{
${ }^{2}$ Martin and Milas [29] examine the spread between the monetary policy rate and an economically relevant borrowing rate and discuss how monetary policy in the UK responded to movements in market rates.
} 
market interest rates in the US, the UK and Switzerland over the period 2005-2008. Section 3 introduces the model. Section 4 discusses optimal policy for the three operating procedures and the resulting volatilities for inflation, the output gap and the yield curve. Section 5 concludes.

\section{Interest rates during the 2007/08 financial crisis}

The analysis in this paper is loosely modelled on the monetary policy operating procedures of three central banks: the Bank of England, the Federal Reserve and the Swiss National Bank. ${ }^{3}$ The operating procedures of these central banks differ little with respect to the implementation tool: all use repo rates with very similar short-term maturities. ${ }^{4}$ However, the three banks express their monetary policy intentions in terms of a target for interest rates which differ quite substantially.

The Bank of England formulates monetary policy in terms of Bank rate, i.e. the repo rate at which the Bank is willing, against eligible collateral, to lend funds to commercial banks. The typical maturity of these repo transactions, which are essentially risk free, is one week. The Federal Reserve's operational target is the federal funds rate, i.e. the rate at which commercial banks lend uncollateralised overnight funds to one another. Thus, the US target rate is a market rate at the very short end of the maturity spectrum which incorporates default and other risks. Before the financial crisis, the Federal Reserve influenced the level of the federal funds rate through repo transactions with overnight and two-week maturity. The Swiss National Bank, finally, announces monetary policy in terms of a target range of typically one percentage point for the three-month CHF libor, which is a rate for uncollateralised three-month funds on the London interbank market. The Swiss National Bank implements its policy using repos of typically one-week maturity. ${ }^{5}$

To illustrate the effect of monetary policy operating procedures on interest rates, Figure

\footnotetext{
${ }^{3}$ The European Central Bank is not considered in this study since the policy rate is the minimum bid rate, which before October 2008 often deviated from the actual price paid by the commercial banks for central bank funds in the variable rate tenders (after the collapse of Lehman Brothers, the ECB adopted fixed-rate tenders). Modelling such a framework is beyond the scope of this paper.

${ }^{4}$ The Federal Reserve moreover buys and sells securities as part of its open market operations. In the crisis, additional instruments such as the Term Auction Facility were introduced.

${ }^{5}$ In a similar setup, the Bank of Canada had a target for the three-month Treasury bill rate until January 1996 (Borio [6]). Regarding the implementation of monetary policy in Switzerland, see Jordan and Kugler [23] and Jordan, Ranaldo and Söderlind [24].
} 
Figure 1: Interest rates, January 2005 to January 2009
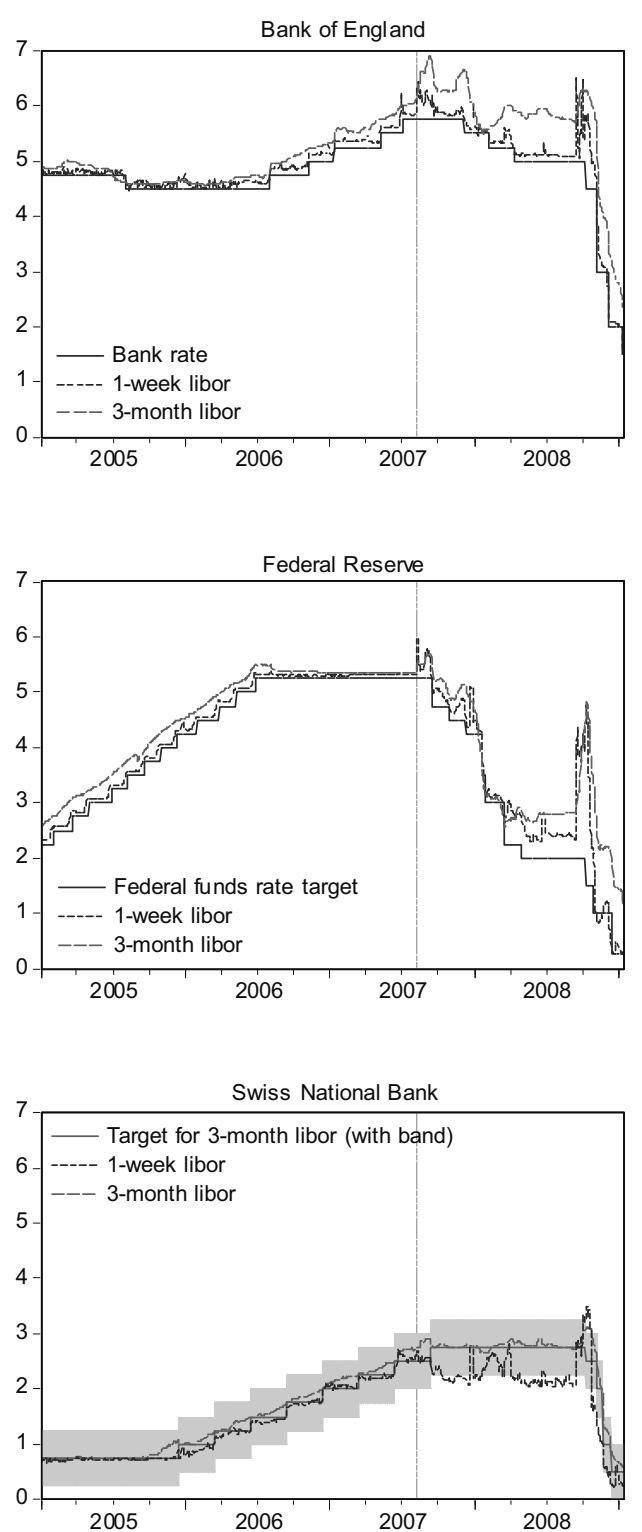

Note: The vertical dashed line represents the onset of the crisis in August 2007. 
1 shows interest rates for the US, the UK and Switzerland over the period January 2005 to January 2009. Interest rates moved closely together before the onset of the crisis in August 2007. The volatility of the spreads then increased and peaked in September and October 2008 after the collapse of Lehman Brothers. It is notable that the three-month libors were more volatile than the one-week libors for GBP and USD, but that the opposite is true for CHF. This is because the Swiss National Bank stabilised the three-month libor by adjusting its short-term repo rates. These repo rate adjustments were translated into movements at the very short end of the yield curve, which consequently was more volatile for CHF than for GBP and USD. The choice of target rate for monetary policy appears to determine which part of the yield curve is stabilised and which maturities adjust to risk shocks, a phenomenon Flemming [18] referred to as "pivoting". This choice in turn might impact on the volatility of the macroeconomy.

\section{The model}

To study how the choice of monetary operating procedure impacts on macroeconomic volatility, we consider an extended version of the canonical New Keynesian model (see e.g. Woodford [42]). We first describe the economy and then discuss the monetary policy problem, which consists of deriving the optimal reaction function for the repo rate, which is the central bank's implementation tool.

\subsection{The economy}

The model economy consists of a hybrid New Keynesian Phillips curve, a consumption Euler equation and a set of equations describing the dynamics of the term structure of interest rates. The hybrid New Keynesian Phillips curve is given by

$$
\pi_{t}=a_{\pi} E_{t} \pi_{t+1}+\left(1-a_{\pi}\right) \pi_{t-1}+a_{y} y_{t}+u_{\pi, t},
$$

where $\pi_{t}$ is the inflation rate, $y_{t}$ the output gap, $a_{\pi}$ a parameter reflecting the degree of forwardlookingness in the price-setting behaviour of firms, and $a_{y}$ a composite parameter capturing the discount rate and the frequency of price adjustments. The exogenous inflationary shock, $u_{\pi, t}$, is assumed to follow an $\mathrm{AR}(1)$ process,

$$
u_{\pi, t}=\rho_{\pi} u_{\pi, t-1}+\sigma_{\pi} e_{\pi, t}
$$

with $0<\rho_{\pi}<1$ and $e_{\pi, t} \sim N(0,1)$. 
The log-linearised consumption Euler equation is given by

$$
y_{t}=b_{y} E_{t} y_{t+1}+\left(1-b_{y}\right) y_{t-1}-b_{r}\left(i_{1, t}-E_{t} \pi_{t+1}-\mu_{1, r}\right)+u_{y, t}
$$

where $i_{1, t}$ denotes the annualised nominal money market interest rate with maturity of one period, $\mu_{1, r}$ the equilibrium one-period real market rate, and $u_{y, t}$ an exogenous demand shock which evolves according to

$$
u_{y, t}=\rho_{y} u_{y, t-1}+\sigma_{y} e_{y, t}
$$

with $0<\rho_{y}<1$ and $e_{y, t} \sim N(0,1)$. Thus, we assume that economic activity depends on the short-term market rate. This assumption is common in the literature. Empirical arguments why economic activity depends mainly on short-term rates include the fact that banks funds themselves mostly at that horizon and that mortgages often are priced off short-term money market rates. That said, policymakers often argue that long-term rather than short-term interest rates impact on economic activity (see e.g. Bernanke [4] and Rudebusch, Sack and Swanson [34]). We therefore consider as a robustness test in Section 4.3 an alternative IS curve in which the average real interest rate matters. In particular,

$$
y_{t}=b_{y} E_{t} y_{t+1}+\left(1-b_{y}\right) y_{t-1}-b_{r}\left(i_{a v, t}-E_{t} \pi_{a v, t+1}-\mu_{a v, r}\right)+u_{y, t},
$$

where $i_{a v, t}$ is the average of the money market rates $i_{j, t}$ with maturities $j=1$ to 12 months,

$$
i_{a v, t}=\frac{1}{12} \sum_{j=1}^{12} i_{j, t},
$$

and average inflation is defined accordingly,

$$
\pi_{a v, t+1}=\frac{1}{12} \sum_{j=1}^{12} E_{t} \pi_{j, t+1},
$$

with $\pi_{j, t}$ the annualised inflation rate over the next $j$ months. Since we model interest rate only out to a horizon of twelve months, this alternative IS curve should be seen as an illustration rather than a realistic description of the role of longer-term rates in the economy. Nevertheless, as Section 4.3 below shows, even within these limitations there are palpable changes in the results. ${ }^{6}$

\footnotetext{
${ }^{6}$ We do not consider an IS curve with only a longer-term rate entering since this raises indeterminacy problems in the 3MR procedure, which we discuss in Section 3.2 below. The reason for this is that if the one-month rate does not enter the IS, it is not pinned down anymore (in the RR and the $1 \mathrm{MR}$ procedures, the smoothing objective discussed below achieves this).
} 
The novel part of the model is that the central bank does not directly control the market rate entering the IS curve, but the repo rate $i_{t}$. The short-term money market rate $i_{1, t}$ deviates from the repo rate by a risk premium $\theta_{1, t}$, so that

$$
i_{1, t}=i_{t}+\theta_{1, t}
$$

This risk premium reflects counterparty risk that arises in a market transaction but does not figure in transactions with the central bank. ${ }^{7}$ We concentrate on default risk, which we see as being dependent on the state of the business cycle. In particular, we assume that the default risk on a loan increases when the output gap is expected to fall. ${ }^{8}$ Thus, the expected output gap at the end of the credit contract matters for the risk premium of the one-period money market interest rate, and we write

$$
\theta_{1, t}=\theta_{1}-c E_{t} y_{t+1}+\varepsilon_{1, t}
$$

where $\theta_{1}$ captures the constant component of the default risk and $c$ denotes the impact of economic activity. The innovation in equation (9) follows an $\mathrm{AR}(1)$ process,

$$
\varepsilon_{1, t}=\rho_{\varepsilon} \varepsilon_{1, t-1}+\sigma_{e, 1} e_{1, t},
$$

with $e_{1, t} \sim N(0,1)$. Longer-term money market interest rates are given by the expectations hypothesis. The $j$-period interest rate $i_{j, t}$ is defined as

$$
i_{j, t}=\tau_{j}+\theta_{j, t}+\frac{1}{j} E_{t} \sum_{k=0}^{j-1} i_{t+k},
$$

where $\tau_{j}$ denotes a constant term premium and $\theta_{j, t}$ the $j$-period risk premium. ${ }^{9}$ The latter, in

${ }^{7}$ Michaud and Upper [31] offer a detailed discussion of the evolution of risk premia during the financial crisis. Using daily data, they find that liquidity matters at high frequencies, while default risk appears to impact at lower frequencies.

${ }^{8}$ Fama and French [16] show that default spreads between risky and essentially riskless bonds are high if business conditions are weak, and Campbell, Lo and MacKinlay [8] argue that risk aversion is time-varying either because of habit formation or agents' heterogeneity. Affine models of the term structure document the empirical relationship between the yield curve and the state of the business cycle as well as inflation (see Ang and Piazzesi [2], Dewachter and Lyrio [11], Hördahl, Tristani and Vestin [22], Kozicki and Tinsley [25] and Piazzesi and Swanson [32]). Emiris [14] studies the term structure of interest rates in a DSGE model and finds that premia are related to shocks to consumption and investment, thus providing a theoretical link between market interest rates and the business cycle.

${ }^{9}$ As an alternative to the expectations hypothesis, Amisano and Tristani [1], Atkeson and Kehoe [3] and Emiris [14] derive expressions for longer-term interest rates in micro-based models with frictions. 
turn, depends on the expected future path of the output gap,

$$
\theta_{j, t}=\theta_{j}-c \frac{1}{j} E_{t} \sum_{k=1}^{j} y_{t+k}+\varepsilon_{j, t},
$$

with

$$
\varepsilon_{j, t}=\rho_{\varepsilon} \varepsilon_{j, t-1}+\sigma_{e, j} e_{j, t},
$$

where the risk innovations $e_{j, t} \sim N(0,1)$ are correlated across maturities. ${ }^{10}$

Finally, we assume that the central bank and the private sector form rational expectations and have access to the same information about the economy.

\subsection{The monetary policy problem}

We assume that the central bank's period loss function is given by

$$
L_{t}=\frac{1}{2} Y_{t}^{\prime} \Lambda Y_{t}
$$

and the intertemporal loss function by

$$
£_{0}=E_{0} \sum_{t=0}^{\infty}(1-\delta) \delta^{t} L_{t},
$$

where $Y_{t}$ is a vector of goal variables, $\delta$ the discount factor and $\Lambda$ the matrix of goal weights that differ between operating procedures. Under the first of our three monetary operating procedures, policy is formulated with the repo rate $i_{t}$. Thus, the target rate of monetary policy and the implementation tool coincide. We refer to this approach as the repo rate operating procedure (RR procedure). Alternatively, policy can seek to steer as target rate the one-period money market rate $i_{1, t}$. This is labeled the one-month money market rate (1MR) procedure. Under the three-month money market rate $(3 \mathrm{MR})$ procedure, finally, policy targets the three-period money market rate $i_{3, t}$.

The central bank minimises variations in inflation and in the output gap under all three operating procedures. Moreover, the central bank is assumed to smooth the target rate, i.e. $i_{t}, i_{1, t}$ or $i_{3, t}$, depending on the procedure. This assumption is supported by the observation that monetary policy tends to be changed gradually with no obvious attempts being made to smooth movements of interest rates at other maturities. ${ }^{11}$ The set of all potential goal variables

\footnotetext{
${ }^{10}$ Svensson [36] discusses the links between different types of premia across different maturities.

${ }^{11}$ On interest rate smoothing, see e.g. Ellis and Lowe [13], English, Nelson and Sack [15], Goodhart [21] and Rudebusch [33].
} 
in equation (13) then is

$$
Y_{t}=\left[\begin{array}{lllll}
\pi_{t} & y_{t} & \Delta i_{t} & \Delta i_{1, t} & \Delta i_{3, t}
\end{array}\right]^{\prime}
$$

where the off-diagonal elements of $\Lambda$ are zero for all operating procedures. The diagonal is given by $\left[\begin{array}{lllll}\lambda_{\pi} & \lambda_{y} & \lambda_{i} & 0 & 0\end{array}\right]$ under the RR procedure, by $\left[\begin{array}{lllll}\lambda_{\pi} & \lambda_{y} & 0 & \lambda_{i} & 0\end{array}\right]$ under the $1 \mathrm{MR}$ procedure and by $\left[\begin{array}{lllll}\lambda_{\pi} & \lambda_{y} & 0 & 0 & \lambda_{i}\end{array}\right]$ under the $3 \mathrm{MR}$ procedure, where $\lambda_{\pi}$ is the weight attached to the goal of stabilising inflation, $\lambda_{y}$ the weight attached to output gap stabilisation and $\lambda_{i}$ the weight attached to target rate smoothing. Thus, the only difference between procedures is the specific target rate smoothed.

To determine the optimal reaction function for the central bank's repo rate, we minimise the loss function with respect to the repo rate $i_{t}$, subject to the structure of the economy as given by equations (1) to (12). The appendix discusses the state space representation of the model and the optimisation under commitment and discretion in detail.

Before proceeding further, a technical difficulty in computing optimal policies for the market rate-based procedures $(1 \mathrm{MR} / 3 \mathrm{MR})$ should be noted. Under these procedures, policymakers smooth either $i_{1, t}$ or $i_{3, t}$, which includes a risk premium that is a function of the expected future path of the output gap. ${ }^{12}$ That path, in turn, depends on monetary policy and thus on the current repo rate $i_{t}$, which is the variable the optimisation is solved for. In other words, defining the loss function for the $1 \mathrm{MR} / 3 \mathrm{MR}$ procedure presupposes the knowledge of the optimal reaction function for $i_{t}$ that minimises this loss function. We tackle the problem by guessing an initial reaction function and iterating until convergence.

\section{Results}

In this section, we first compare the three operating procedures in a baseline specification, assuming that monetary policy is conducted either under commitment and in a timeless perspective (see Svensson and Woodford [39] and Woodford [42]) or under discretion (see Söderlind [35]). We compute the optimal repo rate reaction functions, the impulse response functions and the average volatilities of inflation, the output gap and the yield curve. We then discuss how the results change during financial turmoil, i.e. when risk shocks are larger and more correlated. Next, we consider the variant of the model with the average of the money market rates of hori-

\footnotetext{
${ }^{12}$ We assume that the expected output gap depends in the same way from expected other variables as the current output gap depends on their current values.
} 
zons one to twelve months in the IS curve. Finally, we study how stabilising the level of the yield curve impacts on the results.

\subsection{Baseline case}

The periodicity of the model is assumed to be monthly. The baseline calibration sets the coefficients in the Phillips curve, the consumption Euler equation and the corresponding shock processes to $a_{\pi}=b_{y}=0.8, a_{y}=0.2, b_{r}=0.5, \rho_{\pi}=\rho_{y}=0.9, \rho_{\varepsilon}=0.5$ and $\sigma_{\pi}=\sigma_{y}=0.1 .{ }^{13}$ Central bank preferences are specified by the weights put in the period loss function on inflation stabilisation, output gap stabilisation and target rate smoothing, which we set to $\lambda_{\pi}=\lambda_{y}=1$ and $\lambda_{i}=0.5$, and by the discount factor $\delta=0.999$. For the risk premia, we set $\theta_{1}=\theta_{j}=0.1$, $c=0.25, \sigma_{e, j}=0.01$ and $\sigma_{e, j k}=0.001$ for $j \neq k$. Finally, the constant term premia are modelled as $\tau_{j}=\sqrt{j-1} / 10$, a functional form that matches US pre-crisis data rather well. Given these parameters, we minimise the loss function and obtain the optimal reaction function for the repo rate.

Optimal repo rate reaction functions: Table 1 shows the optimal repo rules for the three operating procedures for commitment (upper panel) and discretion (lower panel). Under commitment, the RR procedure calls for essentially no response of the repo rate to past inflation $(-0.005)$ and the past output gap (0.084), but a stronger reaction to innovations in the Phillips curve (0.388) and in the IS curve (0.983). There is considerable repo rate smoothing (0.463) and a negative response of the repo rate to shocks in the one-month risk premium (-0.339), implying that monetary policy partially absorbs such shocks. Thus, if the risk premium rises, the repo rate is lowered so that the increase in the one-month market rate is smaller than that in $\theta_{1, t}$. However, the repo rate does not fully absorb the shock, since this would require a sharp response that conflicts with the goal of smoothing the target rate. Finally, shocks to the three-month risk premium trigger no repo rate reaction, and the responses to the Lagrange multipliers for the Phillips and IS curves, $\xi_{t-1}^{P C}$ and $\xi_{t-1}^{I S}$, which capture the importance of future interest rate setting under commitment, are small (-0.017 and 0.150).

The 1MR procedure yields a similar optimal repo rate reaction function. The main difference is that innovations in the one-month risk premium are fully absorbed. This implies that risk

\footnotetext{
${ }^{13}$ Robustness tests show that the results presented here do not depend qualitatively on the exact parameter assumptions. It should be noted that, because of the monthly periodicity, the AR coefficients chosen are larger than in the standard literature, which assumes quarterly periodicity, and the standard errors are smaller.
} 
Table 1: Optimal reaction functions in the baseline case

\begin{tabular}{lccccccccccc}
\hline \multicolumn{10}{c}{ Commitment } \\
\hline Procedure & $\pi_{t-1}$ & $y_{t-1}$ & $i_{t-1}$ & $i_{1, t-1}$ & $i_{3, t-1}$ & $u_{\pi, t}$ & $u_{y, t}$ & $\varepsilon_{1, t}$ & $\varepsilon_{3, t}$ & $\xi_{t-1}^{P C}$ & $\xi_{t-1}^{I S}$ \\
\hline RR & -0.005 & 0.084 & 0.463 & 0 & 0 & 0.388 & 0.983 & -0.339 & 0 & -0.017 & 0.150 \\
$1 \mathrm{MR}$ & -0.013 & 0.074 & 0 & 0.453 & 0 & 0.266 & 1.003 & -1 & 0 & -0.026 & 0.115 \\
$3 \mathrm{MR}$ & -0.000 & 0.163 & 0 & 0 & 0.651 & 0.164 & 0.699 & -0.365 & -1.089 & -0.013 & 0.385 \\
\hline \hline & & & & & Discretion & & & & & \\
\hline Procedure & $\pi_{t-1}$ & $y_{t-1}$ & $i_{t-1}$ & $i_{1, t-1}$ & $i_{3, t-1}$ & $u_{\pi, t}$ & $u_{y, t}$ & $\varepsilon_{1, t}$ & $\varepsilon_{3, t}$ & & \\
\hline RR & 0.062 & 0.131 & 0.259 & 0 & 0 & 4.124 & 1.417 & -0.528 & 0 & & \\
$1 \mathrm{MR}$ & 0.060 & 0.129 & 0 & 0.252 & 0 & 3.790 & 1.432 & -1 & 0 & & \\
$3 \mathrm{MR}$ & 0.105 & 0.263 & 0 & 0 & 0.315 & 3.966 & 1.287 & -0.708 & -0.582 & & \\
\hline
\end{tabular}

Note: Repo rate reaction function coefficients for different operating procedures. RR, $1 \mathrm{MR}$ and $3 \mathrm{MR}$ stand for repo rate, one-month and three-month money market rate procedures.

shocks at the one-month horizon do not change the one-month money market rate and thus have no impact on the output gap and inflation. Full absorption is possible under the 1MR procedure since the short-term money market rate is smoothed, rather than the repo rate.

The 3MR procedure calls for a weaker response to inflation and output gap shocks. Innovations in the one-month risk premium are partly, and three-month shocks essentially fully, absorbed. Finally, there is considerable interest rate smoothing with respect to the three-month market rate.

Under discretion, the coefficients on inflation and output gap shocks are much larger than under commitment, and interest rate smoothing is less pronounced. These changes reflect the stabilisation bias discussed in Dennis and Söderström [10] and Woodford [41]. In an economy with forward-looking agents, interest rate smoothing under commitment stabilises expectations and thereby reduces overall macroeconomic volatility. If policy is discretionary, however, policymakers do not follow this optimal gradual response and therefore stabilise the output gap more and inflation less. Compared with commitment, the $\mathrm{RR}$ and the $3 \mathrm{MR}$ procedures react more to one-month risk premium shocks. Three-month shocks trigger a smaller response under the $3 \mathrm{MR}$ procedure, again because there is less weight attached to variables relating to the future. 
Figure 2: Impulse response functions under commitment
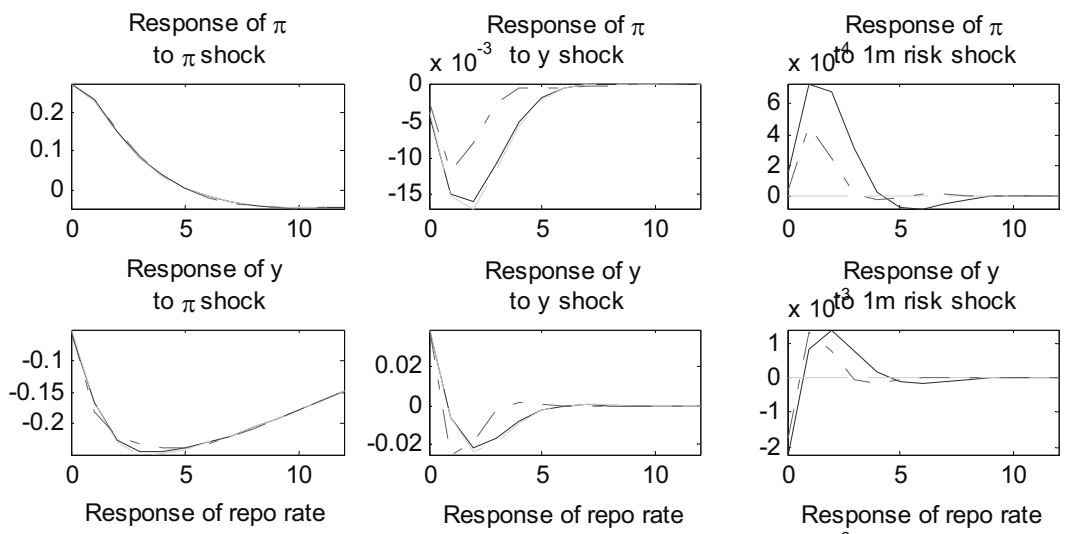

$\mathrm{x} 10^{\text {tỏ }} 1 \mathrm{~m}$ risk shock
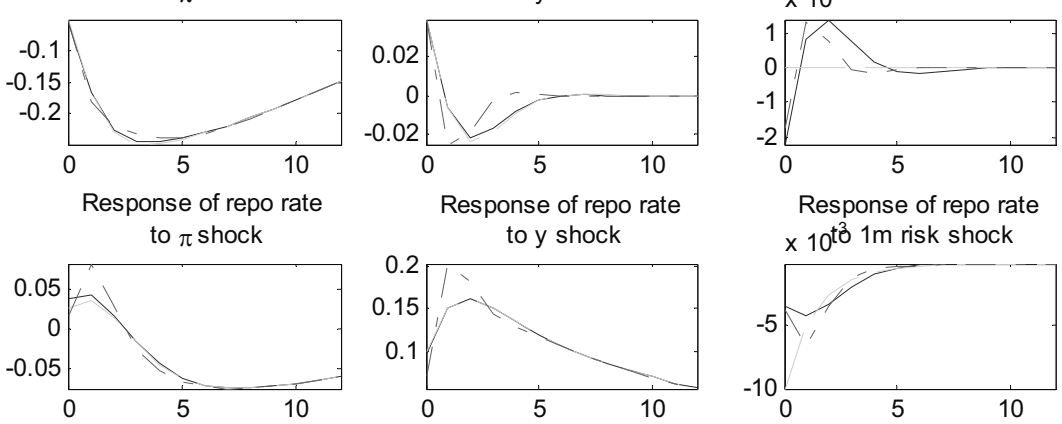

to $y$ shock
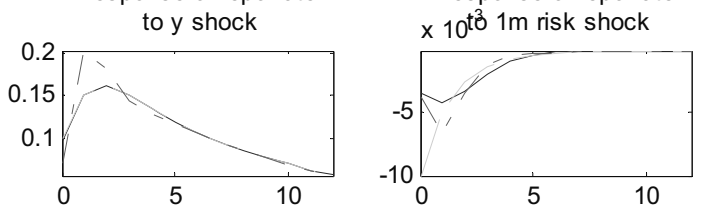

Response of $1 \mathrm{~m}$ market rate to $\pi$ shock to y shock to $1 \mathrm{~m}$ risk shock

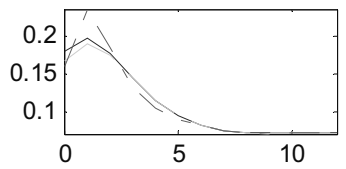

Response of $3 \mathrm{~m}$ market rate to $\pi$ shock

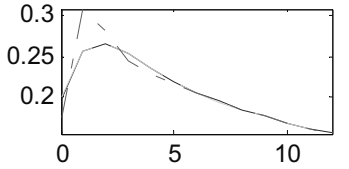

Response of $3 \mathrm{~m}$ market rate to y shock
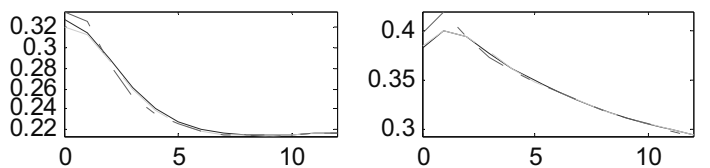

Response of $3 \mathrm{~m}$ market rate

to $1 \mathrm{~m}$ risk shock

Response of $1 \mathrm{~m}$ risk premium

to $\pi$ shock

Response of $1 \mathrm{~m}$ risk premium to $y$ shock
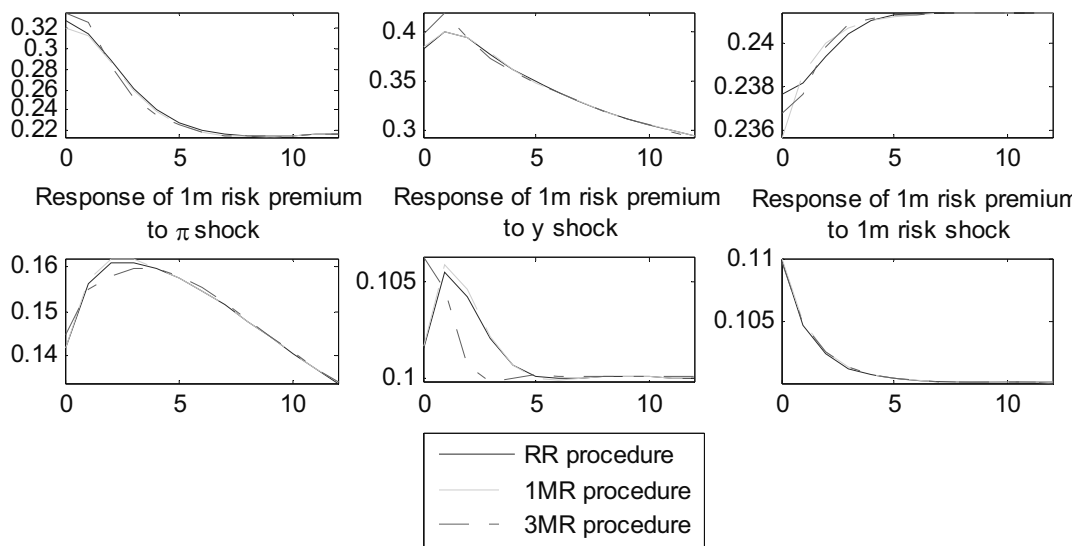

Response of $1 \mathrm{~m}$ risk premium

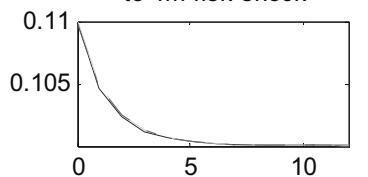

Note: RR, $1 \mathrm{MR}$ and $3 \mathrm{MR}$ stand for repo rate, one-month and three-month money market rate procedures. 
Figure 3: Impulse response functions under discretion
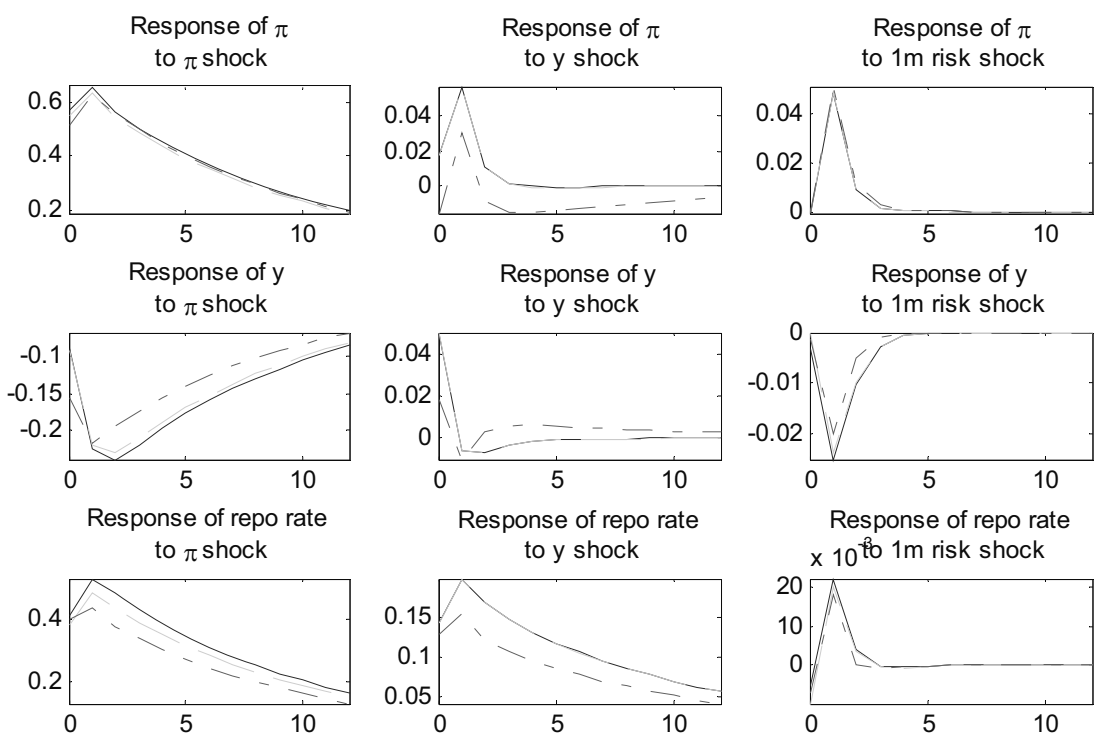

to $\mathrm{y}$ shock
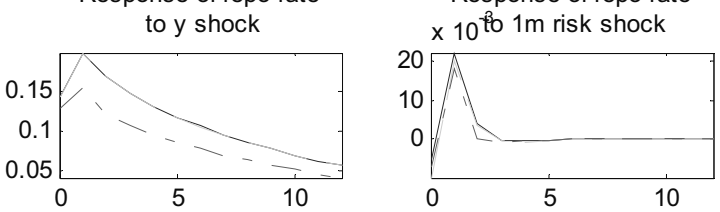

Response of $1 \mathrm{~m}$ market rate to $\pi$ shock

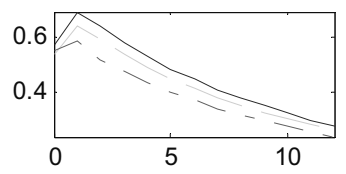

Response of $3 \mathrm{~m}$ market rate to $\pi$ shock

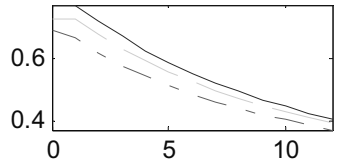

Response of $1 \mathrm{~m}$ risk premium to $\pi$ shock

Response of $1 \mathrm{~m}$ market rate to $y$ shock

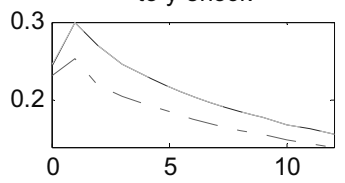

Response of $1 \mathrm{~m}$ market rate to $1 \mathrm{~m}$ risk shock

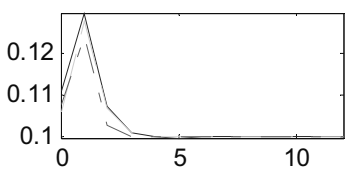

Response of $3 \mathrm{~m}$ market rate to $y$ shock

Response of $3 \mathrm{~m}$ market rate to $1 \mathrm{~m}$ risk shock
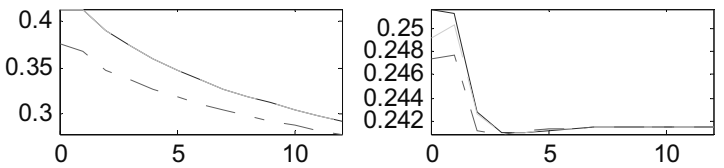

Response of $1 \mathrm{~m}$ risk premium Response of $1 \mathrm{~m}$ risk premium to $y$ shock to $1 \mathrm{~m}$ risk shock
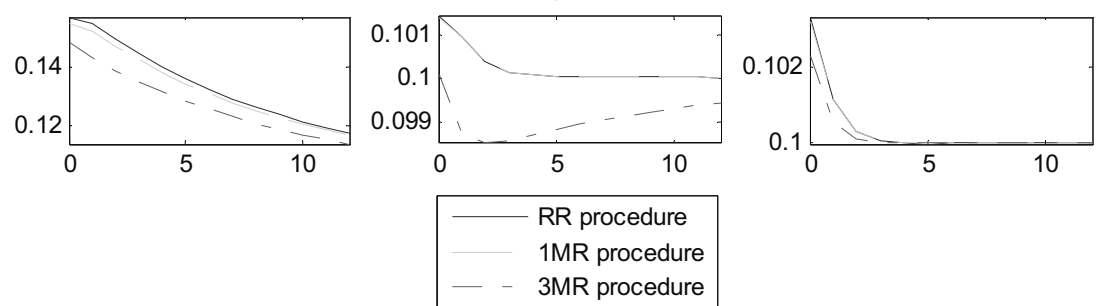

Note: RR, $1 \mathrm{MR}$ and $3 \mathrm{MR}$ stand for repo rate, one-month and three-month money market rate procedures. 
Impulse responses: To evaluate how the choice of monetary operating procedure affects macroeconomic dynamics, we present impulse responses for various shocks under the RR, 1MR and $3 \mathrm{MR}$ procedures. Figure 2 shows the responses under commitment, Figure 3 those under discretion. The first two columns illustrate the impact of a one-standard-deviation shock to inflation and the output gap, respectively, and the last column shows the effect of a shock to the one-month risk premium.

For the case of commitment, the first two plots in the last column of Figure 2 indicate that a risk shock affects inflation and the output gap most under the RR procedure, followed by the 3MR approach. The reason for this is that the cut in the repo rate in response to a risk shock is under these procedures not sufficient to absorb the shock completely. The rise in the risk premium thus implies an increase in the one-month market rate. By contrast, absorption is complete under the $1 \mathrm{MR}$ procedure and as a result, the one-month market rate, inflation and the output gap are essentially unaffected. The three-month market rate declines strongly on impact because of the reduction in the repo rate.

The impulse responses to an inflationary shock are almost identical for all three procedures, reflecting the broad similarities between their optimal reaction functions. A positive inflation shock is undone slowly by tighter monetary policy, which causes the output gap to turn negative. Because of the fall in output, default risk increases and the market rates rise, thus further depressing output before the variables return to equilibrium. A positive output gap shock, finally, drives the repo rate up, and inflation and subsequently the output gap turn negative for some time. Under the $3 \mathrm{MR}$ procedure, the repo rate is raised most strongly, so that the responses of inflation and the output gap to the shock are smaller and faster. The market rates rise in response to an output gap shock under all operating procedures due to the tightening of the repo rate.

For the case of discretion, Figure 3 shows similar responses to an inflation shock. Output gap shocks trigger a more aggressive initial repo rate response because of the stabilisation bias and a faster subsequent reduction of that rate. This makes the output gap return to equilibrium quickly but leads to a temporary build-up in inflation. Similarly, the output gap is stabilised fast after a risk premium shock, at the expense of temporarily higher inflation.

Macroeconomic and interest rate volatility: To compare the monetary operating procedures in terms of welfare we next compute the volatility of the inflation rate, the output gap 
Figure 4: Volatilities in the baseline case

\section{Commitment}

Macroeconomy

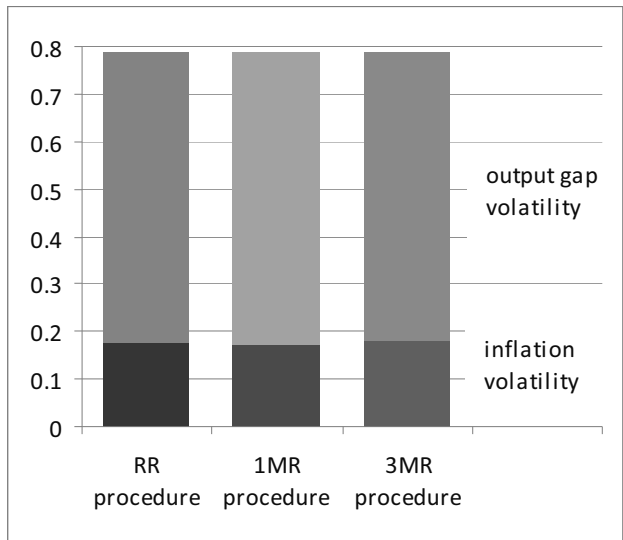

Discretion

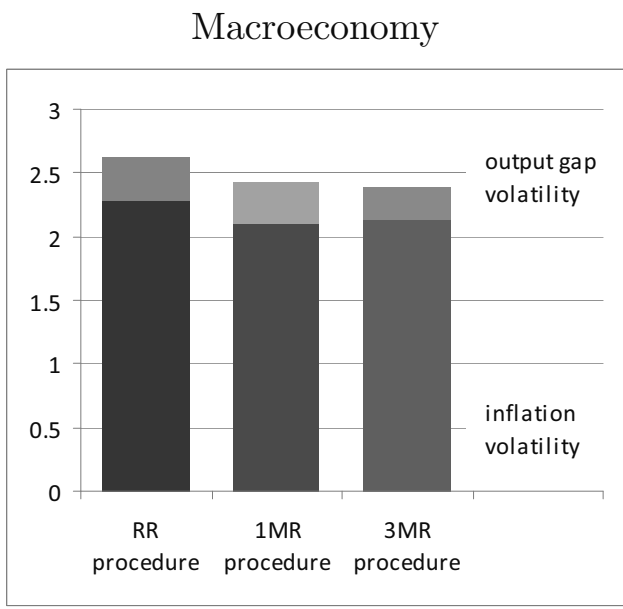

Yield curve

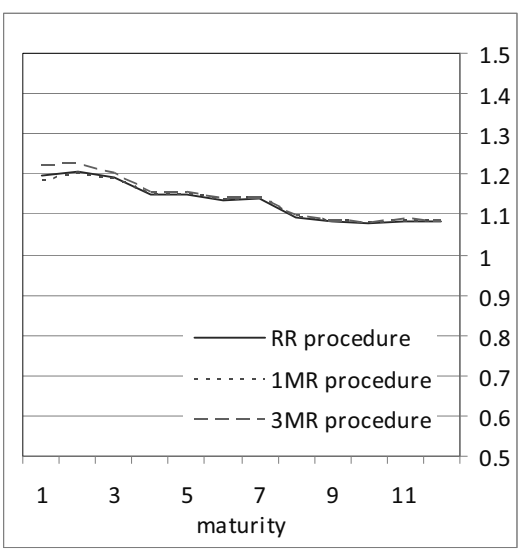

Note: Simulations with 10,000 draws. RR, $1 \mathrm{MR}$ and $3 \mathrm{MR}$ stand for repo rate, one-month and three-month money market rate procedures. 
and the yield curve. For that purpose we perform stochastic simulations. We generate 10,000 draws for each monetary operating procedure. The upper panel of Figure 4 presents the results for commitment, the lower panel for discretion. The left plots show the simulated volatilities for the macroeconomic variables, while volatilities of the market interest rates with maturity $j=1, \ldots, 12$ months are shown in the right plots. In interpreting these volatilities, it is important to remember that the results are biased in favour of the short-term money market rate. This bias arises because of the assumption that this rate matters in the IS curve.

Under commitment, the variability of the macroeconomic variables and the yield curve are virtually identical for the three monetary operating procedures. Under discretion, macroeconomic volatility is higher because monetary policy does not attempt to impact on expectations. Also, the stabilisation bias for the output gap relative to inflation is clearly visible. Macroeconomic volatility is lowest under the $3 \mathrm{MR}$ and $1 \mathrm{MR}$ procedures. It seems thus that using a policy target that refers to a market rate is preferable to a repo rate target. The yield curve is more volatile than under commitment, reflecting the stronger response of policy to shocks. The variability at the short end of the term structure is comparatively low because it is optimal to limit the volatility of the one-month market rate since it enters the IS curve.

Overall, the baseline results suggest that it does not matter much which monetary operating procedure is chosen in times of financial calm if policymakers can commit themselves. This might explain why different approaches are observed in practice. If policy is set in a discretionary fashion, volatilities are lower if a money market rate, rather than the repo rate, is chosen as target rate. We next ask how these results change in times of heightened financial risk.

\subsection{Financial turmoil}

In this section, we study how an increase in the variance and the correlation of the risk shocks similar to that in the financial crisis of 2007/08 affect the results. In particular, we assume an autocorrelation of the risk premium shocks of $\rho_{\varepsilon}=0.9$ (instead of $\left.\rho_{\varepsilon}=0.5\right)$ and multiply the standard errors by one hundred.

Arguably, it is more realistic to assume that monetary policy is set in a discretionary manner in times of crisis. For completeness, we again present also results assuming commitment.

Optimal repo rate reaction functions: Table 2 shows the optimal reaction functions for the three operating procedures. Both under commitment and discretion, the responses to the 
risk premia change for the $\mathrm{RR}$ and the $3 \mathrm{MR}$ procedure, but not for the $1 \mathrm{MR}$ approach. The reason for this is that we only assume different dynamics for the risk premium, movements of which the $1 \mathrm{MR}$ procedure absorbs fully. For the RR procedure, we now find a stronger response to changes in $\varepsilon_{1, t}$ because innovations in the one-month market rate are more protracted and therefore have a larger effect on inflation and the output gap. For the 3MR procedure, by contrast, we find a weaker response both to changes in $\varepsilon_{1, t}$ and $\varepsilon_{3, t}$. This result is due to the fact that the higher autocorrelation of the risk shocks generates the expectation that policy responds for several periods in the same direction after an initial innovation. This expectation causes ceteris paribus a large movement in longer-term market rates, which policymakers under the 3MR procedure however would like to smooth. Therefore, a smaller response to risk shocks becomes desirable as $\rho_{\varepsilon}$ rises.

Table 2: Optimal reaction functions during financial turmoil

\begin{tabular}{lccccccccccc}
\hline \multicolumn{10}{c}{ Commitment } \\
\hline Procedure & $\pi_{t-1}$ & $y_{t-1}$ & $i_{t-1}$ & $i_{1, t-1}$ & $i_{3, t-1}$ & $u_{\pi, t}$ & $u_{y, t}$ & $\varepsilon_{1, t}$ & $\varepsilon_{3, t}$ & $\xi_{t-1}^{P C}$ & $\xi_{t-1}^{I S}$ \\
\hline RR & -0.005 & 0.084 & 0.463 & 0 & 0 & 0.388 & 0.983 & -0.491 & 0 & -0.017 & 0.150 \\
$1 \mathrm{MR}$ & -0.013 & 0.074 & 0 & 0.453 & 0 & 0.266 & 1.003 & -1 & 0 & -0.026 & 0.115 \\
$3 \mathrm{MR}$ & -0.000 & 0.163 & 0 & 0 & 0.651 & 0.164 & 0.669 & -0.350 & -0.720 & -0.013 & 0.385 \\
\hline \hline & & & & & Discretion & & & & & \\
\hline & $\pi_{t-1}$ & $y_{t-1}$ & $i_{t-1}$ & $i_{1, t-1}$ & $i_{3, t-1}$ & $u_{\pi, t}$ & $u_{y, t}$ & $\varepsilon_{1, t}$ & $\varepsilon_{3, t}$ & & \\
\hline $\mathrm{RR}$ & 0.062 & 0.131 & 0.259 & 0 & 0 & 4.124 & 1.417 & -0.708 & 0 & & \\
$1 \mathrm{MR}$ & 0.060 & 0.129 & 0 & 0.252 & 0 & 3.790 & 1.432 & -1.000 & 0 & & \\
$3 \mathrm{MR}$ & 0.105 & 0.263 & 0 & 0 & 0.315 & 3.966 & 1.287 & -0.643 & -0.351 & & \\
\hline
\end{tabular}

Note: Repo rate reaction function coefficients for different operating procedures. RR, $1 \mathrm{MR}$ and $3 \mathrm{MR}$ stand for repo rate, one-month and three-month money market rate procedures.

Macroeconomic and interest rate volatility: The volatilities under commitment are displayed in the upper panel in Figure 5. Comparing them with those from the baseline calibration of the model, we find that macroeconomic volatility has increased under the RR and 3MR procedures but remains essentially unchanged under the $1 \mathrm{MR}$ approach. This is again due to the fact that risk shocks are fully undone by the 1MR procedure. Macroeconomic volatility is 
largest under the $3 \mathrm{MR}$ approach since this procedure absorbs risk premium shocks least. The yield curve volatility in the upper right panel is higher for all procedures due to the larger risk shocks at all horizons. For the $3 \mathrm{MR}$ procedure, the aim of smoothing the three-month rate is now visible as a kink in the yield curve volatility at that horizon.

Figure 5: Volatilities during financial turmoil

\section{Commitment}

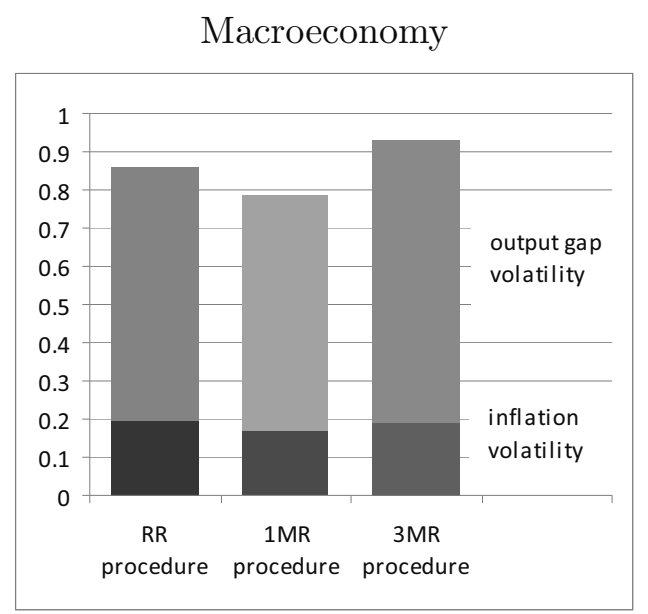

Yield curve

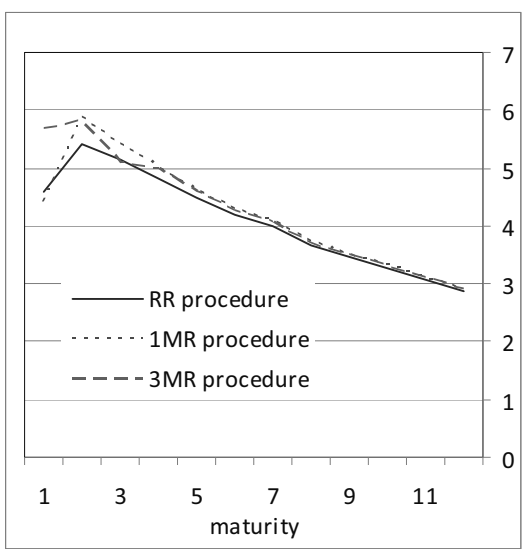

Discretion

Macroeconomy

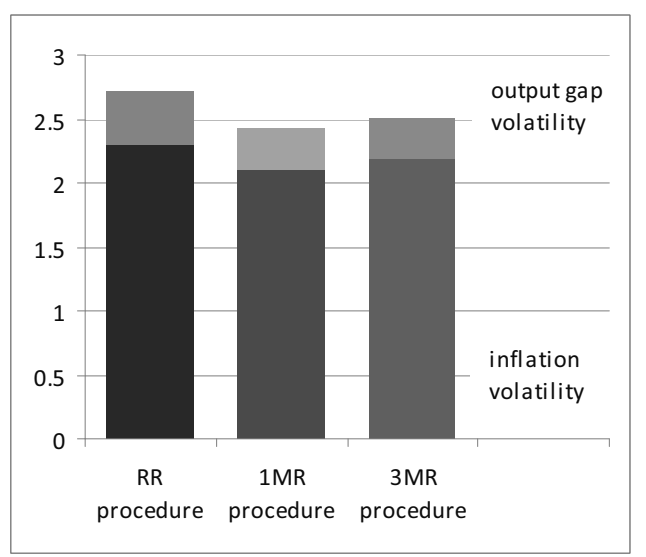

Yield curve

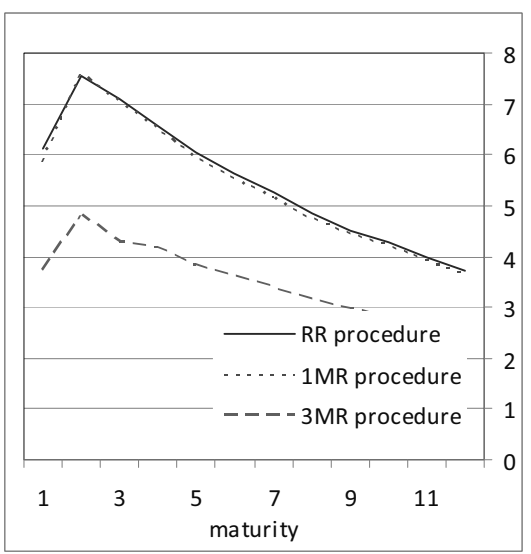

Note: Simulations with 10,000 draws. RR, $1 \mathrm{MR}$ and 3MR stand for repo rate, one-month and three-month money market rate procedures.

Under discretion, arguably the more realistic assumption for times of financial turmoil, we find in the lower part of Figure 5 a clear increase in macroeconomic volatility under the RR 
procedure and a smaller rise for the $3 \mathrm{MR}$ approach. The yield curve volatility is larger, with the smallest increase under the $3 \mathrm{MR}$ procedure. Smoothing a longer-term rate seems to dampen movements along the yield curve when there are large shocks affecting money market rates.

The larger volatility generated under 3MR procedure reflects the fact that the one-month market rate enters the IS curve and biases the results in favour of the 1MR procedure. This assumption is based on the standard linearised New Keynesian model of aggregate output underlying this analysis. Central bankers however often argue that economic activity depends on longer term interest rates and thus that special factors affecting the spread between short term and long term rates will also impact on output. Therefore, we repeat the simulations performed so far under the assumption that a basket of interest rates with maturities lasting from one to twelve months are relevant in the IS curve.

\subsection{Average interest rate in the IS curve}

To examine how the results depend on the choice of the interest rate in the IS curve, we replace the original IS curve (3) in the system with the alternative equation (5) and thus let an unweighted average of the market interest rates with horizons from one to twelve months determine economic activity. Appendix B spells out in detail the adjustments in the model setup.

Optimal repo rate reaction functions: Since now market rates at all horizons impact on the output gap, central banks adjust their repo rate to shocks at any of these horizons. Table 3 shows the optimal reaction functions for the three procedures. The coefficients are broadly similar to the baseline case, though one striking difference is that the degree of interest rate smoothing increases considerably both under commitment and under discretion. The reason for this is that repo rate changes achieve a higher impact on longer-term rates, which depend on the future expected path of $i_{t}$, if they are expected to be followed by similar adjustments in the future. This matches the discussions in Goodhart [21] and Woodford [41], who argue that interest rate smoothing might be a result of policymakers' attempt to impact on long-term rates.

Macroeconomic and interest rate volatility: Figure 6 shows the simulated volatilities of inflation, the output gap and the yield curve in times of financial calm and turmoil. In quiet times the volatilities are very similar no matter which interest rate enters the IS curve.

During the financial turmoil, the different procedures now perform equally well under commitment in terms of macroeconomic volatility. This contrasts with the baseline results. In 
Table 3: Optimal reaction functions with the average interest rate in the IS curve

\begin{tabular}{|c|c|c|c|c|c|c|c|c|c|c|c|}
\hline \multicolumn{12}{|c|}{ Commitment } \\
\hline Procedure & $\pi_{t-1}$ & $y_{t-1}$ & $i_{t-1}$ & $i_{1, t-1}$ & $i_{3, t-1}$ & $u_{\pi, t}$ & $u_{y, t}$ & $\varepsilon_{1, t}$ & $\varepsilon_{2, t}$ & $\varepsilon_{3, t}$ & $\varepsilon_{4, t}$ \\
\hline RR & -0.005 & 0.060 & 0.654 & 0 & 0 & 0.003 & 0.731 & -0.024 & -0.024 & -0.024 & -0.024 \\
\hline $1 \mathrm{MR}$ & -0.015 & 0.053 & 0 & 0.636 & 0 & -0.176 & 0.778 & -0.904 & -0.025 & -0.025 & -0.025 \\
\hline \multirow[t]{2}{*}{$3 \mathrm{MR}$} & -0.010 & 0.036 & 0 & 0 & 0.979 & -0.338 & 0.073 & -0.004 & -0.004 & -1.686 & -0.004 \\
\hline & $\varepsilon_{5, t}$ & $\varepsilon_{6, t}$ & $\varepsilon_{7, t}$ & $\varepsilon_{8, t}$ & $\varepsilon_{9, t}$ & $\varepsilon_{10, t}$ & $\varepsilon_{11, t}$ & $\varepsilon_{12, t}$ & $\xi_{t-1}^{P C}$ & $\xi_{t-1}^{I S}$ & \\
\hline $\mathrm{RR}$ & -0.024 & -0.024 & -0.024 & -0.024 & -0.024 & -0.024 & -0.024 & -0.024 & -0.007 & 0.095 & \\
\hline $1 \mathrm{MR}$ & -0.025 & -0.025 & -0.025 & -0.025 & -0.025 & -0.025 & -0.025 & -0.025 & -0.020 & 0.069 & \\
\hline $3 \mathrm{MR}$ & -0.004 & -0.004 & -0.004 & -0.004 & -0.004 & -0.004 & -0.004 & -0.004 & -0.011 & 0.097 & \\
\hline \multicolumn{12}{|c|}{ Discretion } \\
\hline Procedure & $\pi_{t-1}$ & $y_{t-1}$ & $i_{t-1}$ & $i_{1, t-1}$ & $i_{3, t-1}$ & $u_{\pi, t}$ & $u_{y, t}$ & $\varepsilon_{1, t}$ & $\varepsilon_{2, t}$ & $\varepsilon_{3, t}$ & $\varepsilon_{4, t}$ \\
\hline RR & 0.062 & 0.115 & 0.449 & 0 & 0 & 2.809 & 1.238 & -0.048 & -0.048 & -0.048 & -0.048 \\
\hline $1 \mathrm{MR}$ & 0.061 & 0.118 & 0 & 0.436 & 0 & 2.555 & 1.290 & -0.808 & -0.050 & -0.050 & -0.050 \\
\hline \multirow[t]{2}{*}{$3 \mathrm{MR}$} & 0.122 & 0.284 & 0 & 0 & 0.858 & 2.791 & 1.133 & -0.069 & -0.069 & -1.602 & -0.069 \\
\hline & $\varepsilon_{5, t}$ & $\varepsilon_{6, t}$ & $\varepsilon_{7, t}$ & $\varepsilon_{8, t}$ & $\varepsilon_{9, t}$ & $\varepsilon_{10, t}$ & $\varepsilon_{11, t}$ & $\varepsilon_{12, t}$ & & & \\
\hline $\mathrm{RR}$ & -0.048 & -0.048 & -0.048 & -0.048 & -0.048 & -0.048 & -0.048 & -0.048 & & & \\
\hline $1 \mathrm{MR}$ & -0.050 & -0.050 & -0.050 & -0.050 & -0.050 & -0.050 & -0.050 & -0.050 & & & \\
\hline $3 \mathrm{MR}$ & -0.069 & -0.069 & -0.069 & -0.069 & -0.069 & -0.069 & -0.069 & -0.069 & & & \\
\hline
\end{tabular}

Note: Repo rate reaction function coefficients for different operating procedures, assuming the IS curve is given by equation (5) rather than equation (3). RR, $1 \mathrm{MR}$ and $3 \mathrm{MR}$ stand for repo rate, one-month and three-month money market rate procedures. 
Figure 6: Volatilities with the average interest rate in the IS curve

Financial calm: Commitment
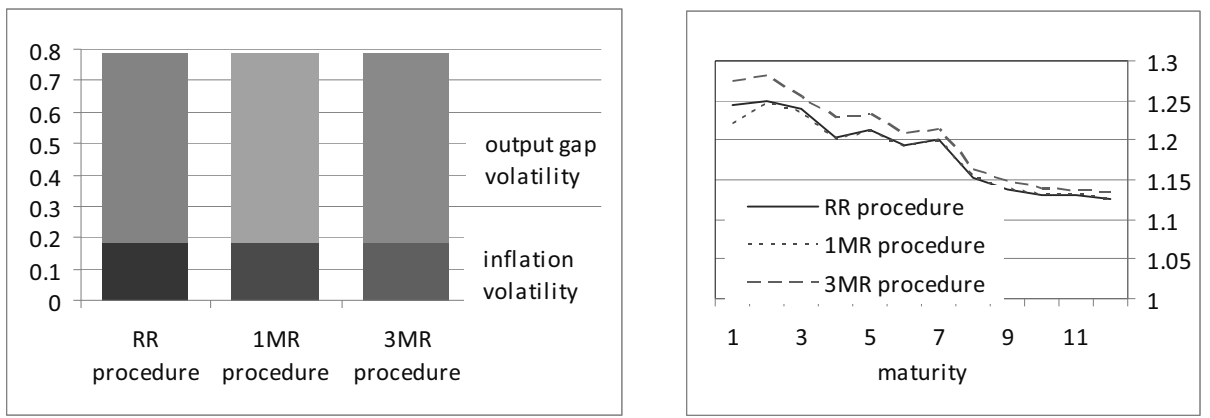

Financial calm: Discretion
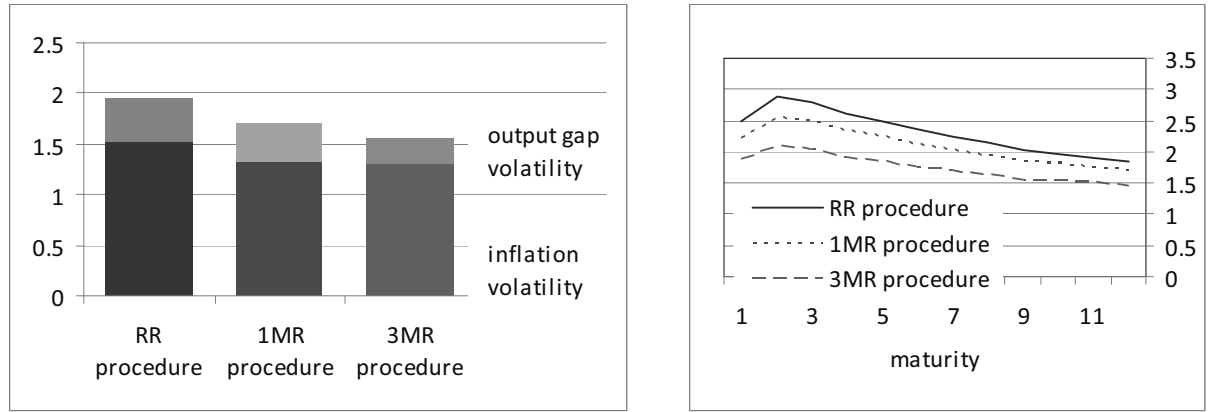

Financial turmoil: Commitment
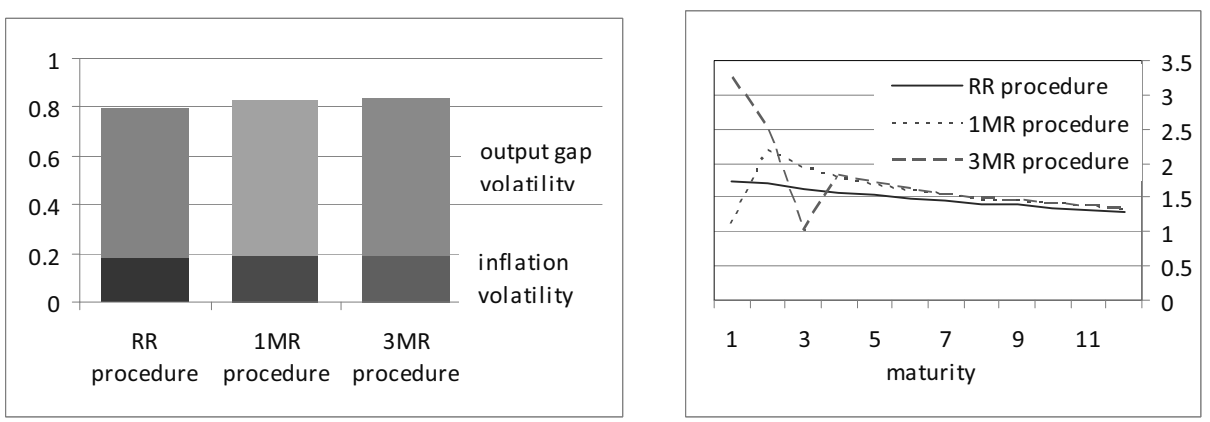

Financial turmoil: Discretion
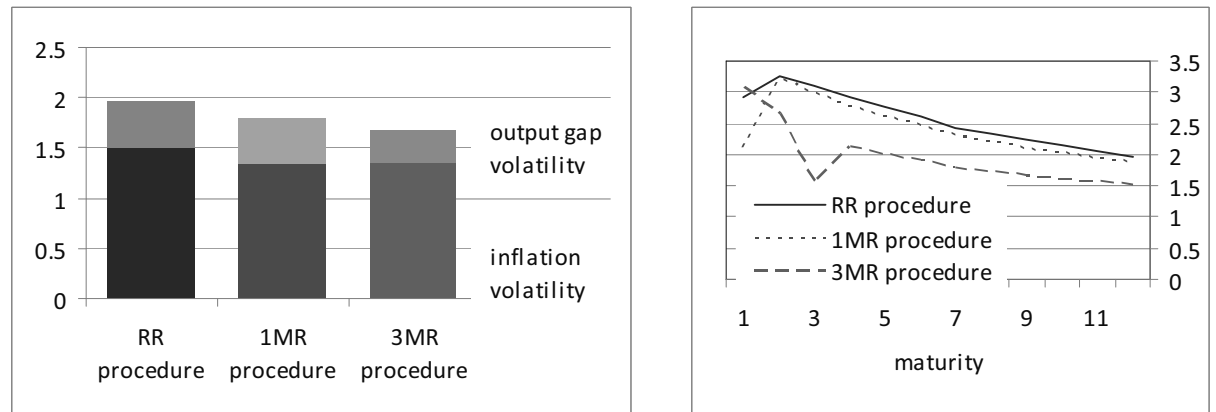

Note: Simulations with 10,000 draws. RR, $1 \mathrm{MR}$ and $3 \mathrm{MR}$ stand for repo rate, one-month and three-month money market rate procedures. 
Figure 5, where we assumed that only the one-month repo rate matters in the IS curve, the $1 \mathrm{MR}$ procedure, which smooths that rate and thus responds most aggressively to shocks at that horizon, outperformed the RR and the 3MR approach. Now, smoothing one particular interest rate does not constitute a clear advantage for any of the models, since no single interest rate matters for economic activity. That said, the smoothing objectives show up in the volatility of the yield curve, with little variability in the one-month (three-month) market rates for the $1 \mathrm{MR}$ $(3 \mathrm{MR})$ procedure. If there is financial turmoil and if monetary policy is set in a discretionary way, the 3MR procedure yields the lowest macroeconomic volatility in Figure 6. This finding again differs from the baseline results, where the $1 \mathrm{MR}$ procedure yielded the most stable inflation and output gap. The reason for this change is that the $3 \mathrm{MR}$ procedure attaches more weight to the future and therefore implicitly also to the average interest rate that enters the IS curve. At the same time, this approach yields comparatively little yield curve volatility.

In sum, deciding which interest rate matters in the IS curve has important implications for the choice of monetary operating procedure. If one assumes that economic activity is driven by the one-month market rate, using the $1 \mathrm{MR}$ procedure seems attractive. If longer-term rates matter for the output gap as well, the 3MR procedure appears most robust in minimising macroeconomic volatility.

\subsection{Targeting the yield curve}

Having considered how the model changes if we let longer-term interest rates have an effect on the output gap, we now return to the baseline model with the one-month market rate in the IS curve but ask what happens if the central bank dislikes movements of the yield curve as a whole. This seems an interesting exercise in the aftermath of the financial crisis since there have been calls for monetary policy to control financial market prices and asset prices in particular. While our model neither allows us to examine asset prices in detail nor models boom-bust cycles, a drop in the level of the yield curve can be thought of as boosting asset prices. A policy trying to avoid asset price booms should thus prevent shifts in the level of the yield curve.

To analyse this kind of policy, we expand the set of goal variables to include the level of the yield curve. More precisely, policymakers are assumed to minimise the variability of the yield curve around its mean, which is given for the different maturities $j$ by $\theta_{j}+\tau_{j}$. We denote the weight attached to the goal of stabilising the yield curve by $\lambda_{y c}$. Modelling interest rates up to 
twelve months out, $j=1,2, \ldots, 12$, the expanded vector of goal variables is therefore

$$
Y_{t}=\left[\begin{array}{llllllll}
\pi_{t} & y_{t} & \Delta i_{t} & \Delta i_{1, t} & \Delta i_{3, t} & i_{1, t} & \ldots & i_{12, t}
\end{array}\right]^{\prime},
$$

where the weight attached to each money market rate is $\lambda_{y c} / 12$.

Table 4: Optimal reaction functions under yield curve targeting

\begin{tabular}{lccccccccccc}
\hline \multicolumn{10}{c}{ Commitment } \\
\hline Procedure & $\pi_{t-1}$ & $y_{t-1}$ & $i_{t-1}$ & $i_{1, t-1}$ & $i_{3, t-1}$ & $u_{\pi, t}$ & $u_{y, t}$ & $\varepsilon_{1, t}$ & $\varepsilon_{2, t}$ & $\varepsilon_{3, t}$ & $\varepsilon_{4, t}$ \\
\hline RR & -0.005 & 0.068 & 0.409 & 0 & 0 & 0.234 & 0.733 & -0.340 & -0.035 & -0.023 & -0.017 \\
1MR & -0.013 & 0.060 & 0 & 0.401 & 0 & 0.141 & 0.783 & -0.936 & -0.034 & -0.022 & -0.016 \\
$3 \mathrm{MR}$ & -0.004 & 0.113 & 0 & 0 & 0.431 & 0.062 & 0.543 & -0.439 & -0.075 & -0.764 & -0.037 \\
\hline & $\varepsilon_{5, t}$ & $\varepsilon_{6, t}$ & $\varepsilon_{7, t}$ & $\varepsilon_{8, t}$ & $\varepsilon_{9, t}$ & $\varepsilon_{10, t}$ & $\varepsilon_{11, t}$ & $\varepsilon_{12, t}$ & $\xi_{t-1}^{P C}$ & $\xi_{t-1}^{I S}$ & \\
\hline RR & -0.014 & -0.011 & -0.010 & -0.009 & -0.008 & -0.007 & -0.006 & -0.006 & -0.015 & 0.122 & \\
$1 \mathrm{MR}$ & -0.013 & -0.011 & -0.009 & -0.008 & -0.007 & -0.006 & -0.006 & -0.005 & -0.024 & 0.092 & \\
$3 \mathrm{MR}$ & -0.030 & -0.025 & -0.021 & -0.019 & -0.017 & -0.015 & -0.014 & -0.012 & -0.015 & 0.253 & \\
\hline \hline & & & & & Discretion & & & & & \\
\hline Procedure & $\pi_{t-1}$ & $y_{t-1}$ & $i_{t-1}$ & $i_{1, t-1}$ & $i_{3, t-1}$ & $u_{\pi, t}$ & $u_{y, t}$ & $\varepsilon_{1, t}$ & $\varepsilon_{2, t}$ & $\varepsilon_{3, t}$ & $\varepsilon_{4, t}$ \\
\hline RR & 0.058 & 0.123 & 0.242 & 0 & 0 & 5.545 & 1.855 & -0.545 & -0.007 & -0.005 & -0.003 \\
$1 \mathrm{MR}$ & 0.057 & 0123 & 0 & 0.236 & 0 & 5.217 & 1.902 & -0.989 & -0.006 & -0.004 & -0.003 \\
$3 \mathrm{MR}$ & 0.090 & 0.220 & 0 & 0 & 0.244 & 5.961 & 1.864 & -0.736 & -0.019 & -0.464 & -0.009 \\
\hline & $\varepsilon_{5, t}$ & $\varepsilon_{6, t}$ & $\varepsilon_{7, t}$ & $\varepsilon_{8, t}$ & $\varepsilon_{9, t}$ & $\varepsilon_{10, t}$ & $\varepsilon_{11, t}$ & $\varepsilon_{12, t}$ & & & \\
\hline RR & -0.003 & -0.002 & -0.002 & -0.002 & -0.002 & -0.001 & -0.001 & -0.001 & & & \\
$1 \mathrm{MR}$ & -0.002 & -0.002 & -0.002 & -0.001 & -0.001 & -0.001 & -0.001 & -0.001 & & & \\
$3 \mathrm{MR}$ & -0.007 & -0.006 & -0.005 & -0.005 & -0.004 & -0.004 & -0.003 & -0.003 & & & \\
\hline
\end{tabular}

Note: Repo rate reaction function coefficients for different operating procedures, $\lambda_{y c}=1$. RR, 1MR and 3MR stand for repo rate, one-month and three-month money market rate procedures.

Optimal repo rate reaction functions: Table 4 presents the optimal repo rate rules for the three operating procedures assuming $\lambda_{y c}=1$. Comparing the coefficients with those in Table 1 , we see that the expansion of the set of goal variables has little effect on the optimal reaction functions for the RR and $1 \mathrm{MR}$ procedures both under commitment and discretion. The main 
change is that the goal of stabilising the yield curve increases the number of shocks monetary policy responds to. As a consequence, there now is a reaction not only to the one-month risk premium shock but also to the two-month to twelve-month risk premium shocks. Quantitatively, the response to risk shocks beyond the one-month time horizon is essentially zero.

The repo rate reaction function changes more for the $3 \mathrm{MR}$ procedure, both under commitment and discretion. In particular, there is less smoothing of the three-month rate but a more aggressive response to one-month risk shocks. The reason for this is that under yield curve targeting also this procedure attaches some weight to the one-month market rate.

Macroeconomic and interest rate volatility: Figure 7 shows the simulated volatilities of inflation, the output gap and the term structure. To examine the impact of yield curve targeting, we let $\lambda_{y c}$ increase in a stepwise manner from 0.1 to 1 . It can be seen that the variability of the economy rises slightly under commitment and strongly under discretion. While it is perhaps not surprising that the variances of inflation and the output gap become larger when policymakers attempt to achieve an additional goal, it is noteworthy that the variance of the yield curve also increases. This is due to the fact that a more variable output gap raises the volatility of default risk and hence of the yield curve. The effect is stronger under discretion since policymakers take expectations, which drive the yield curve, as given.

\section{Conclusions}

In this paper, we examine how the choice of monetary operating procedure influences the volatility of inflation, the output gap and the yield curve. Although highly stylised, the three procedures considered are designed to capture key differences between operating frameworks adopted by the Bank of England, the Federal Reserve and the Swiss National Bank. We use a simple New Keynesian model where the implementation tool for monetary policy is the short-term repo rate in all three cases, but the procedures differ in terms of the interest rate targeted by the central bank.

The results suggest that in normal times volatilities resulting from the use of the three procedures are similar under commitment. Under discretion, the macroeconomic volatility is comparatively high if the central bank uses the repo rate as official policy target rate. The procedures based on market rates provide better results in this case. In times of financial distress, with large and highly correlated risk premium shocks affecting market rates, the repo rate 
Figure 7: Volatilities under yield curve targeting
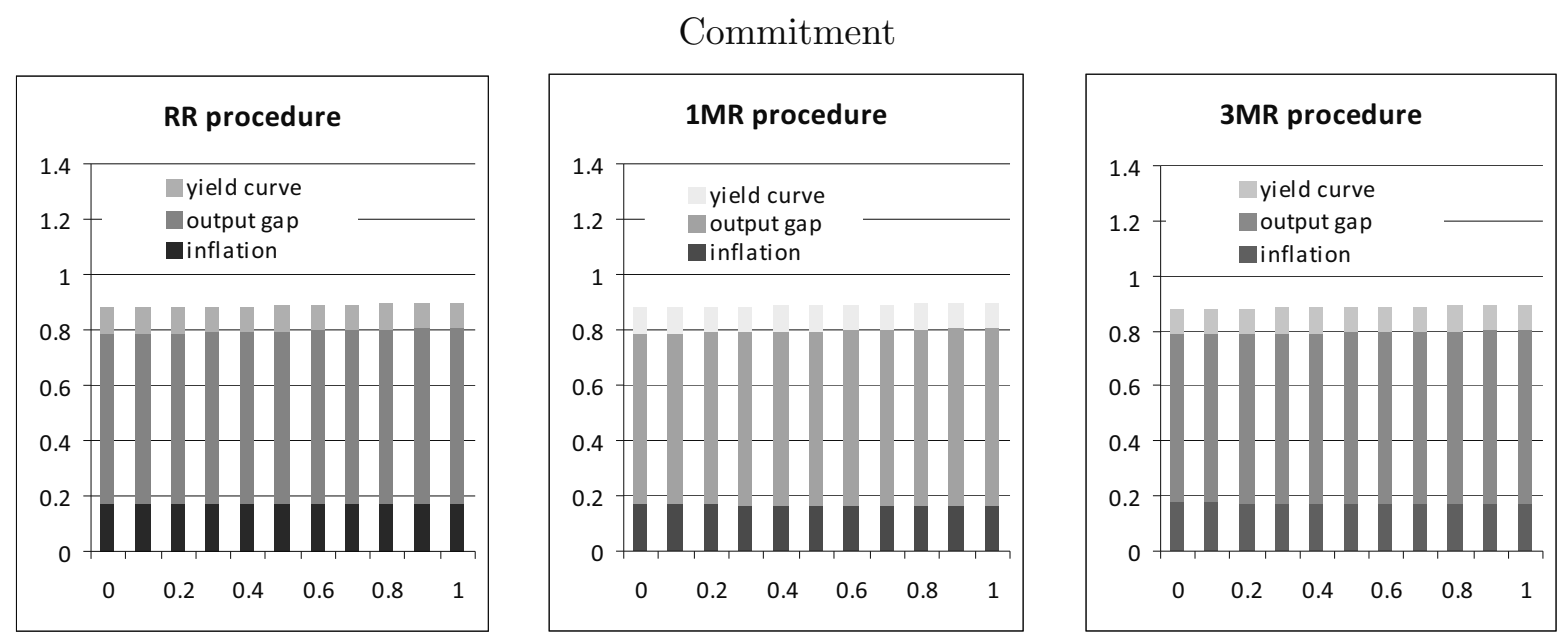

Discretion
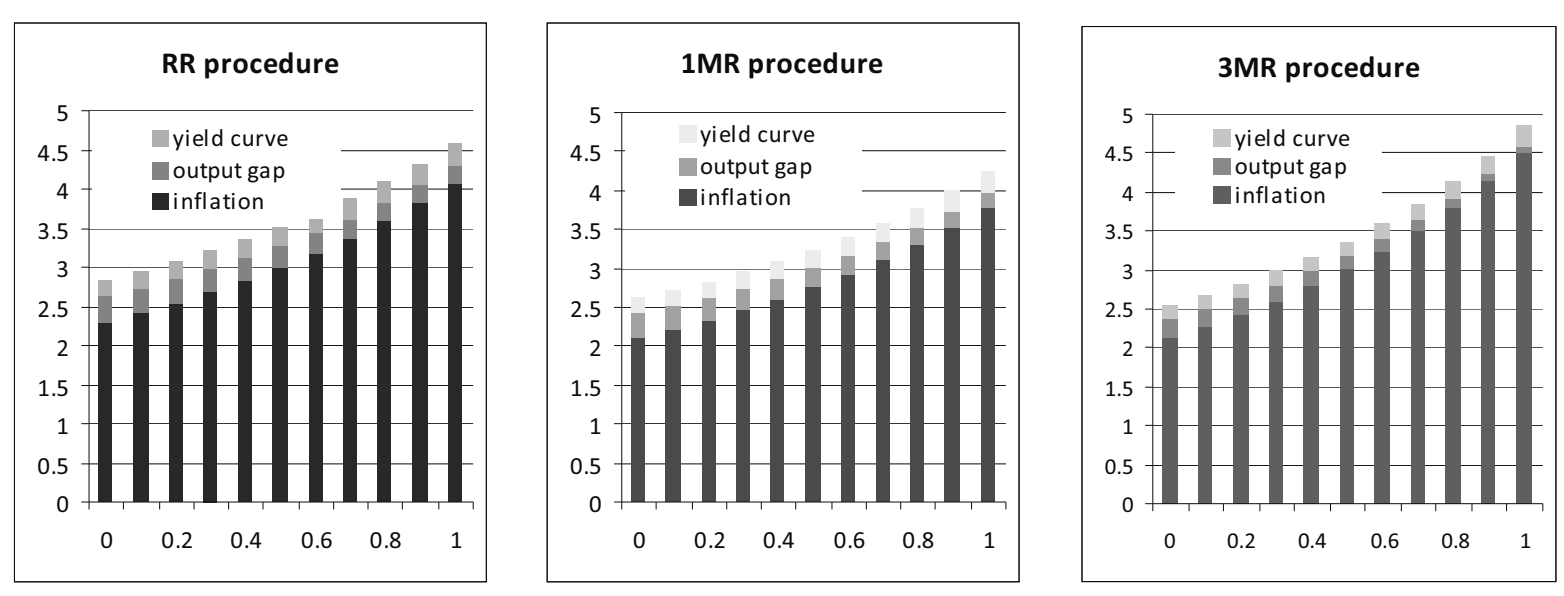

Note: Simulations with 10,000 draws. RR, $1 \mathrm{MR}$ and $3 \mathrm{MR}$ stand for repo rate, one-month and three-month money market rate procedures.

Weight on yield curve variance $\lambda_{y c}$ increasing from 0 to 1. 
procedure again yields high macroeconomic volatility, both under discretion and commitment. Under commitment and large financial shocks, the longer-term money market rate procedure performs poorly in the baseline model. However, this is due to the modelling assumption that the short-term money market rate enters the IS curve. If we instead let the average market rate over horizons of one to twelve months impact on the output gap, the longer-term market rate procedure with its focus on the future becomes attractive. Under discretion, finally, the market-rate based procedures again yield lower macroeconomic volatility than the repo-rate based procedure.

To sum up, none of the three operating procedures studied in this paper is superior in all circumstances. Arguably, this explains why there has not been a convergence to a single operating approach in practice. That being said, it appears that a procedure in which policy targets a money market rate performs best in periods of large shocks to the risk premium such as in the recent past. 


\section{A Optimisation with the one-month market rate in the IS curve}

\section{A.1 Commitment}

The model can be rewritten in state space form,

$$
\begin{gathered}
X_{t+1}=A_{10}+A_{11} X_{t}+A_{12} x_{t}+B_{1} i_{t}+C e_{t+1}, \\
E_{t} H x_{t+1}=A_{21} X_{t}+A_{22} x_{t}+B_{2} i_{t} .
\end{gathered}
$$

where $X_{t}$ is a vector with $n_{X}=31$ predetermined variables

$$
\underset{31 \times 1}{X_{t}}=\left[\begin{array}{lllllllllllll}
\pi_{t-1} & y_{t-1} & i_{t-1} & u_{\pi, t} & u_{y, t} & \varepsilon_{1, t} & \ldots & \varepsilon_{12, t} & \varepsilon_{1, t-1} & \ldots & \varepsilon_{12, t-1} & i_{1, t-1} & i_{3, t-1}
\end{array}\right]^{\prime}
$$

$x_{t}$ is a $2 \times 1$-vector of forward-looking variables, $x_{t}=\left[\begin{array}{ll}\pi_{t} & y_{t}\end{array}\right]^{\prime}$ in period $t$, the vector $i_{t}$ is a scalar containing the monetary policy implementation rate, $i_{t}$, and $e_{t}$ is an $n_{X}$-vector of white noise innovations to the $\mathrm{AR}(1)$ error processes of inflation, the output gap and the risk premia of market interest rates,

$$
\underset{31 \times 1}{e_{t}}=\left[\begin{array}{lllllllll}
0 & 0 & 0 & e_{\pi, t+1} & e_{y, t+1} & e_{1, t+1} & \ldots & e_{12, t} & \mathbf{0}_{1 x 14}
\end{array}\right]^{\prime}
$$

Next, we expand the vector of predetermined variables

$$
\widetilde{X}_{t}=\left[\begin{array}{ll}
X_{t} & \Xi_{t-1}
\end{array}\right]^{\prime}
$$

where $\Xi_{t}=\left[\begin{array}{ll}\Xi_{t}^{P C} & \Xi_{t}^{I S}\end{array}\right]^{\prime}$ contains the Lagrange multipliers for the Phillips and the IS curve and rewrite the state space system as

$$
\widetilde{X}_{t+1}=\widetilde{A}_{10}+\widetilde{A}_{11} \widetilde{X}_{t}+\widetilde{A}_{12} x_{t}+\widetilde{B}_{1} i_{t}+\widetilde{C} e_{t+1}
$$

and

$$
E_{t} H x_{t+1}=A_{21} \tilde{X}_{t}+A_{22} x_{t}+B_{2} i_{t} .
$$

The matrices $\widetilde{A}_{10}, \widetilde{A}_{11}, \widetilde{A}_{12}, \widetilde{B}_{1}, \widetilde{C} \widetilde{C}^{\prime}, H, A_{21}, A_{22}$ and $B_{2}$ are given by

$$
\underset{33 \times 1}{\widetilde{A}_{10}}=\left[\begin{array}{lllll}
\mathbf{0}_{1 \times 29} & \theta_{1}+\tau_{1} & \theta_{3}+\tau_{3} & 0 & 0
\end{array}\right]^{\prime},
$$




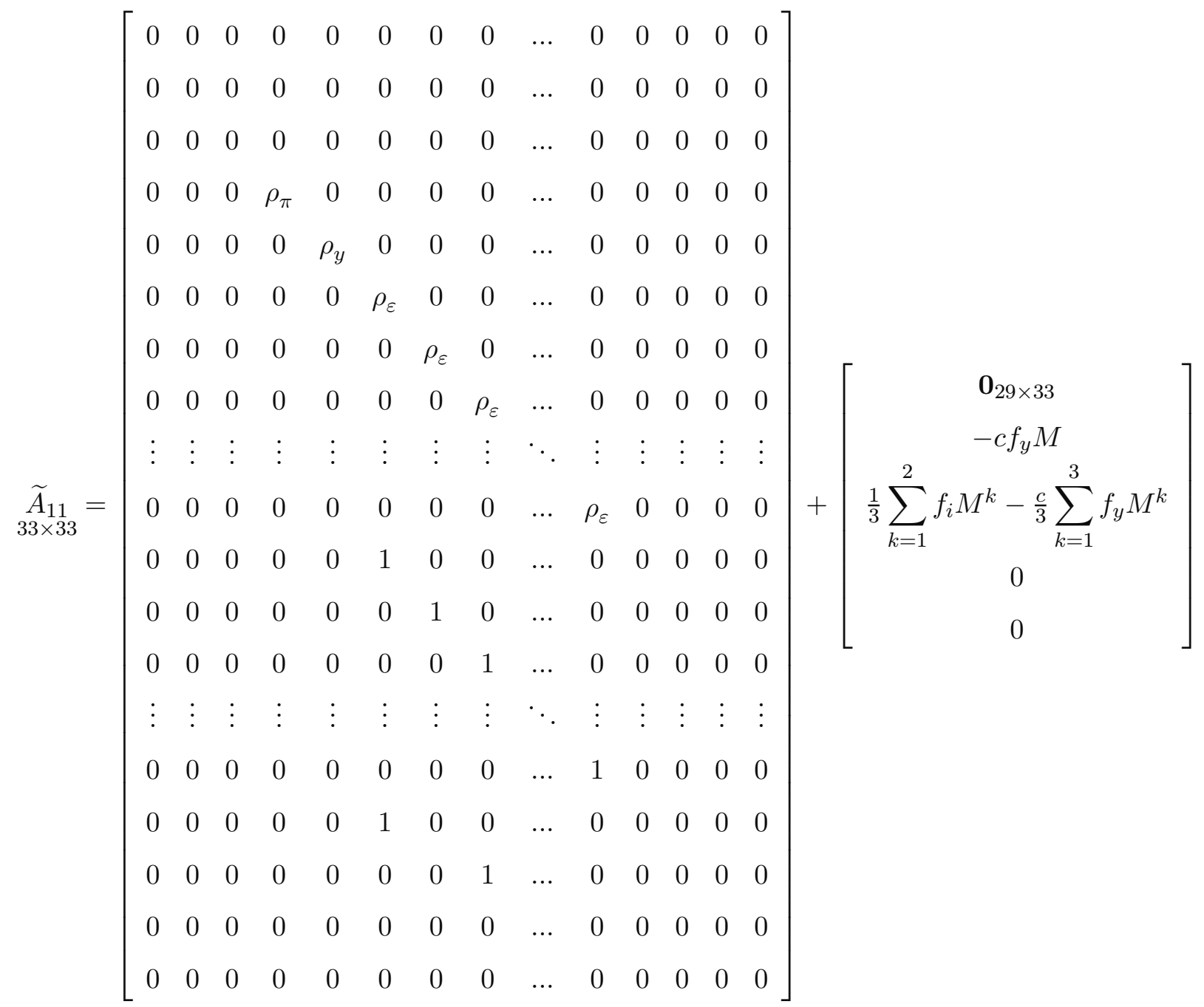

(with the elements in the last matrix explained below),

$$
\begin{gathered}
\underset{33 \times 2}{\widetilde{A}_{12}}=\left[\begin{array}{ccc}
1 & 0 & \mathbf{0}_{1 \times 31} \\
0 & 1 & \mathbf{0}_{1 \times 31}
\end{array}\right]^{\prime}, \\
\underset{33 \times 1}{\widetilde{B}_{1}}=\left[\begin{array}{llllllll}
0 & 0 & 1 & \mathbf{0}_{1 \times 26} & 1 & 1 / 3 & 0 & 0
\end{array}\right]^{\prime}
\end{gathered}
$$




$$
\begin{aligned}
& \underset{33 \times 33}{\widetilde{C} \widetilde{C}^{\prime}}=\left[\begin{array}{cccccccccccccc}
0 & 0 & 0 & 0 & 0 & 0 & 0 & \ldots & 0 & 0 & 0 & 0 & 0 & 0 \\
0 & 0 & 0 & 0 & 0 & 0 & 0 & \ldots & 0 & 0 & 0 & 0 & 0 & 0 \\
0 & 0 & 0 & 0 & 0 & 0 & 0 & \ldots & 0 & 0 & 0 & 0 & 0 & 0 \\
0 & 0 & 0 & \sigma_{\pi}^{2} & 0 & 0 & 0 & \ldots & 0 & 0 & 0 & 0 & 0 & 0 \\
0 & 0 & 0 & 0 & \sigma_{y}^{2} & 0 & 0 & \ldots & 0 & 0 & 0 & 0 & 0 & 0 \\
0 & 0 & 0 & 0 & 0 & \sigma_{\varepsilon, 1}^{2} & \sigma_{\varepsilon, 1,2} & \ldots & \sigma_{\varepsilon, 1,11} & \sigma_{\varepsilon, 1,12} & 0 & 0 & 0 & 0 \\
0 & 0 & 0 & 0 & 0 & \sigma_{\varepsilon, 1,2} & \sigma_{\varepsilon, 2}^{2} & \ldots & \sigma_{\varepsilon, 2,11} & \sigma_{\varepsilon, 2,12} & 0 & 0 & 0 & 0 \\
\vdots & \vdots & \vdots & \vdots & \vdots & \vdots & \vdots & \ddots & \vdots & \vdots & \vdots & \vdots & \vdots & \vdots \\
0 & 0 & 0 & 0 & 0 & \sigma_{\varepsilon, 1,11} & \sigma_{\varepsilon, 2,11} & \ldots & \sigma_{\varepsilon, 11}^{2} & \sigma_{\varepsilon, 11,12} & 0 & 0 & 0 & 0 \\
0 & 0 & 0 & 0 & 0 & \sigma_{\varepsilon, 1,12} & \sigma_{\varepsilon, 2,12} & \ldots & \sigma_{\varepsilon, 11,12} & \sigma_{\varepsilon, 12}^{2} & 0 & 0 & 0 & 0 \\
0 & 0 & 0 & 0 & 0 & 0 & 0 & \ldots & 0 & 0 & 0 & 0 & 0 & 0 \\
0 & 0 & 0 & 0 & 0 & 0 & 0 & \ldots & 0 & 0 & 0 & 0 & 0 & 0 \\
0 & 0 & 0 & 0 & 0 & 0 & 0 & \ldots & 0 & 0 & 0 & 0 & 0 & 0 \\
0 & 0 & 0 & 0 & 0 & 0 & 0 & \ldots & 0 & 0 & 0 & 0 & 0 & 0
\end{array}\right], \\
& H=\left[\begin{array}{cc}
a_{\pi} & 0 \\
b_{r} & b_{y}+b_{r} c
\end{array}\right] \\
& \widetilde{A}_{21}=\left[\begin{array}{ccccccc}
-\left(1-a_{\pi}\right) & 0 & 0 & -1 & 0 & 0 & \mathbf{0}_{1 \times 27} \\
0 & -\left(1-b_{y}\right) & 0 & 0 & -1 & b_{r} & \mathbf{0}_{1 \times 27}
\end{array}\right] \text {, } \\
& A_{22}=\left[\begin{array}{cc}
1 & -a_{y} \\
0 & 1
\end{array}\right] \text { and } B_{2}=\left[\begin{array}{c}
0 \\
b_{r}
\end{array}\right]
\end{aligned}
$$

Under operating procedures that steer money market rates, the target rate $i_{1, t}$ or $i_{3, t}$, respectively, contains a risk premium that depends on the expected future path of the output gap. Since $y_{t}$ is a state variable, these expectations are driven by optimal policy, which thus should be used as an input to the optimisation problem but at the same time is its solution. We solve this problem by assuming starting values for optimal policy and then iterating until convergence. In particular, we define the optimal output gap as

$$
y_{t}=f_{y} \widetilde{X}_{t}
$$

and the optimal repo rate as

$$
i_{t}=f_{i} \widetilde{X}_{t} .
$$


These definitions are used in setting up the matrix $\widetilde{A}_{11}$ above. There, the risk premium for the one-month rate is given by

$$
\theta_{1, t}=\theta_{1}-c E_{t} y_{t+1}+\varepsilon_{1, t}=\theta_{1}-c f_{y} M \tilde{X}_{t}+\varepsilon_{1, t}
$$

since

$$
E_{t} \widetilde{X}_{t+1}=M \widetilde{X}_{t}
$$

with $M$ the optimal linear projection matrix defined below. Similarly, the three-month risk premium is

$$
\theta_{3, t}=\theta_{3}-\frac{c}{j} E_{t} \sum_{k=1}^{3} y_{t+k}+\varepsilon_{3, t}=\theta_{3}-\frac{c}{j} \sum_{k=1}^{3} f_{y} M^{k} \widetilde{X}_{t}+\varepsilon_{j, t},
$$

The money market rates in equation (A1) above thus are defined as

$$
i_{1, t}=\theta_{1}+i_{t}-c f_{y} M \widetilde{X}_{t}+\varepsilon_{1, t}
$$

and

$$
i_{3, t}=\theta_{3}+\frac{1}{3} i_{1, t}+\frac{1}{3} \sum_{k=1}^{2} f_{i} M^{k} \widetilde{X}_{t}-\frac{c}{3} \sum_{k=1}^{3} f_{y} M^{k} \widetilde{X}_{t}+\varepsilon_{3, t},
$$

where the first summation sign captures the expectations hypothesis and relies on

$$
E_{t} i_{t+j}=f_{i} M^{j} \tilde{X}_{t}
$$

To link the goal variables $Y_{t}=\left[\begin{array}{llllllll}\pi_{t} & y_{t} & \Delta i_{t} & \Delta i_{1, t} & \Delta i_{3, t} & i_{1, t} & \ldots & i_{12, t}\end{array}\right]^{\prime}$ to the other variables in the model, we define

$$
Y_{t}=D\left[\begin{array}{lllll}
X_{t} & \Xi_{t-1} & x_{t} & \xi_{t} & i_{t}
\end{array}\right]^{\prime}
$$

where $n_{Y}=17$ and where $\xi_{t}=\left[\begin{array}{ll}\xi_{t}^{P C} & \xi_{t}^{I S}\end{array}\right]^{\prime}=\Xi_{t}$ are Lagrange multipliers that account for the dynamics of the forward-looking variables. 
Matrix $D$ is given by

$$
\begin{aligned}
& \underset{17 \times 38}{D}=\left[\begin{array}{cccccccccccccccccc}
0 & 0 & 0 & 0 & 0 & 0 & 0 & 0 & \ldots & 0 & \ldots & 0 & 0 & 1 & 0 & 0 & 0 & 0 \\
0 & 0 & 0 & 0 & 0 & 0 & 0 & 0 & \ldots & 0 & \ldots & 0 & 0 & 0 & 1 & 0 & 0 & 0 \\
0 & 0 & -1 & 0 & 0 & 0 & 0 & 0 & \ldots & 0 & \ldots & 0 & 0 & 0 & 0 & 0 & 0 & 1 \\
0 & 0 & 0 & 0 & 0 & 1 & 0 & 0 & \ldots & 0 & \ldots & -1 & 0 & 0 & 0 & 0 & 0 & 1 \\
0 & 0 & 0 & 0 & 0 & 0 & 0 & 1 & \ldots & 0 & \ldots & 0 & -1 & 0 & 0 & 0 & 0 & 1 / 3 \\
0 & 0 & 0 & 0 & 0 & 1 & 0 & 0 & \ldots & 0 & \ldots & 0 & 0 & 0 & 0 & 0 & 0 & 1 \\
0 & 0 & 0 & 0 & 0 & 0 & 1 & 0 & \ldots & 0 & \ldots & 0 & 0 & 0 & 0 & 0 & 0 & 1 / 2 \\
0 & 0 & 0 & 0 & 0 & 0 & 0 & 1 & \ldots & 0 & \ldots & 0 & 0 & 0 & 0 & 0 & 0 & 1 / 3 \\
\vdots & \vdots & \vdots & \vdots & \vdots & \vdots & \vdots & \vdots & \ddots & \vdots & \ddots & \vdots & \vdots & \vdots & \vdots & \vdots & \vdots & \vdots \\
0 & 0 & 0 & 0 & 0 & 0 & 0 & 0 & \ldots & 1 & \ldots & 0 & 0 & 0 & 0 & 0 & 0 & 1 / 12
\end{array}\right] \\
& +\left[\begin{array}{c}
0_{3 \times 38} \\
-c f_{y} M \mid 0_{1 \times 5} \\
\frac{1}{3} \sum_{k=1}^{2} f_{i} M^{k}-\frac{c}{3} \sum_{k=1}^{3} f_{y} M^{k} \mid 0_{1 \times 5} \\
-c f_{y} M \mid 0_{1 \times 5} \\
\frac{1}{2} f_{i} M-\frac{c}{2} \sum_{k=1}^{2} f_{y} M^{k} \mid 0_{1 \times 5} \\
\vdots \\
\frac{1}{12} \sum_{k=1}^{11} f_{i} M^{k}-\frac{c}{12} \sum_{k=1}^{12} f_{y} M^{k} \mid 0_{1 \times 5}
\end{array}\right]
\end{aligned}
$$

The period loss function in matrix notation is given by

$$
\begin{aligned}
L_{t} & =\frac{1}{2} Y_{t}^{\prime} \Lambda Y_{t}=\frac{1}{2}\left[\begin{array}{lllll}
X_{t} & \Xi_{t-1} & x_{t} & \xi_{t} & i_{t}
\end{array}\right] D^{\prime} \Lambda D\left[\begin{array}{lllll}
X_{t} & \Xi_{t-1} & x_{t} & \xi_{t} & i_{t}
\end{array}\right]^{\prime} \\
& =\frac{1}{2}\left[\begin{array}{lllll}
X_{t} & \Xi_{t-1} & x_{t} & \xi_{t} & i_{t}
\end{array}\right] W\left[\begin{array}{lllll}
X_{t} & \Xi_{t-1} & x_{t} & \xi_{t} & i_{t}
\end{array}\right]^{\prime} .
\end{aligned}
$$

We solve the model using the dual saddlepoint approach discussed in Marcet and Marimon [28]. We follow Svensson and Williams [38] and define the dual period loss function as

$$
\begin{aligned}
\widetilde{L}_{t} & =L_{t}+\Xi_{t}^{\prime}\left(H x_{t+1}-\widetilde{A}_{21} \widetilde{X}_{t}-A_{22} x_{t}-B_{2} i_{t}\right) \\
& =L_{t}+\Xi_{t}^{\prime}\left(-\widetilde{A}_{21} \widetilde{X}_{t}-A_{22} x_{t}-B_{2} i_{t}\right)+\frac{1}{\delta} \Xi_{t-1}^{\prime} H x_{t} \\
& =L_{t}+\xi_{t}^{\prime}\left(-\widetilde{A}_{21} \widetilde{X}_{t}-A_{22} x_{t}-B_{2} i_{t}\right)+\frac{1}{\delta} \Xi_{t-1}^{\prime} H x_{t}
\end{aligned}
$$


where the second equality comes from the definition $\Xi_{-1}=0$. Using equation (13), equation (A4) can be rewritten as

$$
\begin{aligned}
\widetilde{L}_{t} & =L_{t}+\xi_{t}^{\prime}\left(-\widetilde{A}_{21} \widetilde{X}_{t}-A_{22} x_{t}-B_{2} i_{t}\right)+\frac{1}{\delta} \Xi_{t-1}^{\prime} H x_{t} \\
& =\frac{1}{2}\left[\begin{array}{ll}
\widetilde{X}_{t} & \widetilde{i}_{t}
\end{array}\right] \widetilde{W}\left[\begin{array}{cc}
\widetilde{X}_{t} & \widetilde{i}_{t}
\end{array}\right]^{\prime},
\end{aligned}
$$

where

$$
\widetilde{W}=W+\left[\begin{array}{ccccc}
0 & 0 & 0 & -\widetilde{A}_{21}^{\prime} & 0 \\
0 & 0 & \frac{1}{\delta} H & 0 & 0 \\
0 & \frac{1}{\delta} H^{\prime} & 0 & -A_{22}^{\prime} & 0 \\
-\widetilde{A}_{21} & 0 & -A_{22} & 0 & -B_{2} \\
0 & 0 & 0 & -B_{2}^{\prime} & 0
\end{array}\right]
$$

Equation (A5) is the quadratic loss function in the optimal regulator problem. The linear transition equation for the predetermined variables is given by

$$
\widetilde{X}_{t+1}=\widetilde{A}_{11} \widetilde{X}_{t}+\widetilde{B} \widetilde{i}_{t}+\widetilde{C} e_{t+1},
$$

with

$$
\widetilde{B}=\left(\left[\begin{array}{ccc}
\widetilde{A}_{12} & 0_{\left(n_{X}+n_{x}\right) \times n_{x}} & \widetilde{B}_{1}
\end{array}\right]+\left[\begin{array}{ccc}
0_{n_{X} \times n_{x}} & 0_{n_{X} \times n_{x}} & 0_{n_{X} \times n_{i}} \\
0_{n_{x} \times n_{x}} & I_{n_{x} \times n_{x}} & 0_{n_{x} \times n_{i}}
\end{array}\right]\right),
$$

where the identity matrix captures $\Xi_{t}=\xi_{t}$. The value function $V\left(\widetilde{X}_{t}\right)$ of the saddlepoint problem is quadratic,

$$
V\left(\widetilde{X}_{t}\right)=\left[(1-\delta) \widetilde{X}_{t}^{\prime} V \widetilde{X}_{t}+\delta \omega\right]
$$

where $\omega$ is a scalar. The Bellman equation can therefore be written as

$$
(1-\delta) \widetilde{X}_{t}^{\prime} V \widetilde{X}_{t}+\delta \omega=(1-\delta) \max _{\left\{\xi_{t}\right\}_{t \geq 0}} \min _{\left\{x_{t}, i_{t}\right\}_{t \geq 0}}\left\{\widetilde{L}_{t}+\delta E_{t}\left[\widetilde{X}_{t+1}^{\prime} V \widetilde{X}_{t+1}+\frac{\delta}{1-\delta} \omega\right]\right\} .
$$

Iterating over the resulting Riccati equation yields the optimal solution

$$
\widetilde{i}_{t}=F \widetilde{X}_{t},
$$

where

$$
\begin{gathered}
F=-\left(R+\delta \widetilde{B}^{\prime} V \widetilde{B}\right)^{-1}\left(N^{\prime}+\delta \widetilde{B}^{\prime} V \widetilde{A}_{11}\right), \\
M=\widetilde{A}_{11}+\widetilde{B} F
\end{gathered}
$$

and

$$
V=Q+\delta \widetilde{A}_{11}^{\prime} V \widetilde{A}_{11}-\left(N+\delta \widetilde{B}^{\prime} V \widetilde{A}_{11}\right)^{\prime}\left(R+\delta \widetilde{B}^{\prime} V \widetilde{B}\right)^{-1}\left(N^{\prime}+\delta \widetilde{B}^{\prime} V \widetilde{A}_{11}\right)
$$


with

$$
\widetilde{W}=\left[\begin{array}{cc}
Q & N \\
N^{\prime} & R
\end{array}\right]
$$

partitioned conformably with $\widetilde{X}_{t}$ and $\widetilde{i}_{t}$. The optimal rule $f_{i}$ for the repo rate, equation (A3), is given as the last line in equation (A6) and equation (A2), which captures the dynamics of the output gap, is the second line of equation (A6).

\section{A.2 Discretion}

To derive the optimal repo rules under discretion, we define $A_{10}$ as the first $n_{X}$ elements of $\widetilde{A}_{10}$, $A_{11}$ as the first $n_{X}$ rows and columns of $\widetilde{A}_{11}, A_{12}$ as the first $n_{X}$ rows of $\widetilde{A}_{12}, A_{21}$ as the first $n_{X}$ columns of $\widetilde{A}_{21}, B_{1}$ as the first $n_{X}$ elements of $\widetilde{B}_{1}, C C^{\prime}$ as the first $n_{X}$ rows and columns of $\widetilde{C} \widetilde{C}^{\prime}$ and $D$ as $\widetilde{D}$ without the columns referring to $\Xi_{t-1}$ and $\xi_{t}$. We then write the period loss function as

$$
L_{t}=\frac{1}{2}\left[\begin{array}{c}
X_{t} \\
x_{t} \\
i_{t}
\end{array}\right]^{\prime} W\left[\begin{array}{c}
X_{t} \\
x_{t} \\
i_{t}
\end{array}\right]
$$

with

$$
W=D^{\prime} \Lambda D
$$

Under discretion, the repo rate $i_{t}$ is chosen to minimise equation (A7) subject to

$$
\begin{gathered}
{\left[\begin{array}{c}
X_{t+1} \\
E_{t} H x_{t+1}
\end{array}\right]=\left[\begin{array}{c}
A_{10} \\
0
\end{array}\right]+\left[\begin{array}{cc}
A_{11} & A_{12} \\
A_{21} & A_{22}
\end{array}\right]\left[\begin{array}{c}
X_{t} \\
x_{t}
\end{array}\right]+\left[\begin{array}{c}
B_{1} \\
B_{2}
\end{array}\right] i_{t}+\left[\begin{array}{c}
C \\
0
\end{array}\right] e_{t+1}} \\
i_{t+1}=F_{t+1} X_{t+1}
\end{gathered}
$$

and

$$
x_{t+1}=G_{t+1} X_{t+1},
$$

where $F_{t+1}$ and $G_{t+1}$ are determined in the optimisation in the next period and are assumed to be known today. Taking expectations, combining equations (A8) to (A10) and solving for $x_{t}$ yields

$$
x_{t}=\bar{A}_{t} X_{t}+\bar{B}_{t} i_{t}
$$

with

$$
\bar{A}_{t}=\left(A_{22}-H G_{t+1} A_{12}\right)^{-1}\left(H G_{t+1} A_{11}-A_{21}\right)
$$


and

$$
\bar{B}_{t}=\left(A_{22}-H G_{t+1} A_{12}\right)^{-1}\left(H G_{t+1} B_{1}-B_{2}\right) .
$$

From this it follows that

$$
X_{t+1}=\widehat{A}_{t} X_{t}+\widehat{B}_{t} i_{t}+C e_{t+1}
$$

with

$$
\widehat{A}_{t}=A_{11}+A_{12} \bar{A}_{t}
$$

and

$$
\widehat{B}_{t}=B_{1}+A_{12} \bar{B}_{t}
$$

Using equation (A11) in equation (A7) yields

$$
L_{t}=\frac{1}{2}\left[\begin{array}{c}
X_{t} \\
i_{t}
\end{array}\right]^{\prime}\left[\begin{array}{cc}
Q_{t} & N_{t} \\
N_{t}^{\prime} & R_{t}
\end{array}\right]\left[\begin{array}{c}
X_{t} \\
i_{t}
\end{array}\right],
$$

where

$$
\begin{gathered}
Q_{t}=W_{X X}+W_{X x} \bar{A}_{t}+\bar{A}_{t}^{\prime} W_{X x}^{\prime}+\bar{A}_{t}^{\prime} W_{x x} \bar{A}_{t}, \\
N_{t}=W_{X x} \bar{B}_{t}+\bar{A}_{t}^{\prime} W_{x x} \bar{B}_{t}+W_{X i}+\bar{A}_{t}^{\prime} W_{x i}
\end{gathered}
$$

and

$$
R_{t}=W_{i i}+\bar{B}_{t}^{\prime} W_{x x} \bar{B}_{t}+\bar{B}_{t}^{\prime} W_{x i}+W_{x i}^{\prime} \bar{B}_{t} .
$$

The Bellman equation can be written as

$$
\frac{1}{2}\left[(1-\delta) X_{t}^{\prime} V_{t} X_{t}+\delta \omega_{t}\right]=(1-\delta) \min _{i_{t}}\left[L_{t}+\delta E_{t} \frac{1}{2}\left(X_{t+1}^{\prime} V_{t+1} X_{t+1}+\frac{\delta}{1-\delta} \omega_{t}\right)\right] .
$$

From the first order condition, we obtain

$$
F_{t}=-\left(R_{t}+\delta \widehat{B}_{t}^{\prime} V_{t+1} \widehat{B}_{t}\right)^{-1}\left(N_{t}+\delta \widehat{B}_{t}^{\prime} V_{t+1} \widehat{A}_{t}\right)
$$

and

$$
G_{t}=\bar{A}_{t}+\bar{B}_{t} F_{t}
$$

and we denote the corresponding equilibrium functions by $F$ and $G$. Forecasts of $X_{t}$ are based on

$$
X_{t+1}=M X_{t}+C e_{t+1}
$$

with

$$
M=\widehat{A}+\widehat{B} F,
$$


where $\widehat{A}$ and $\widehat{B}$ are the fixed points of the mapping from $\left(\widehat{A}_{t+1}, \widehat{B}_{t+1}\right)$ to $\left(\widehat{A}_{t}, \widehat{B}_{t}\right)$. The equilibrium function $F$ determines the expected future interest rate that enters $A_{11}$ and $D$ in the iterations that are performed until the model converges. Expected future output gaps are determined by $G$.

\section{B Optimisation with the average interest rate in the IS curve}

If the IS curve is given by equation (5) rather than (3), we need to adjust matrices $H, \widetilde{A}_{21}$ and $B_{2}$ to

$$
\begin{aligned}
& H=\left[\begin{array}{cc}
a_{\pi} & 0 \\
b_{r} \frac{1}{12} \sum_{j=1}^{12} \frac{1}{j} & b_{y}+b_{r} c \frac{1}{12} \sum_{j=1}^{12} \frac{1}{j}
\end{array}\right], \\
& \widetilde{A}_{21}=\left[\begin{array}{cccccccccc}
-\left(1-a_{\pi}\right) & 0 & 0 & -1 & 0 & 0 & 0 & \ldots & 0 & \mathbf{0}_{1 \times 16} \\
0 & -\left(1-b_{y}\right) & 0 & 0 & -1 & \frac{1}{12} b_{r} & \frac{1}{12} b_{r} & \ldots & \frac{1}{12} b_{r} & \mathbf{0}_{1 \times 16}
\end{array}\right] \\
& +\left[\frac{1}{12} \sum_{j=2}^{12} \frac{1}{j}\left[f_{i} \sum_{k=1}^{j-1} E_{t} \widetilde{X}_{t+k}-\left(c f_{y}+f_{\pi}\right) \sum_{k=2}^{j} E_{t} \widetilde{X}_{t+k}\right]\right]
\end{aligned}
$$

and

$$
B_{2}=\left[\begin{array}{c}
0 \\
b_{r} \frac{1}{12} \sum_{j=1}^{12} \frac{1}{j}
\end{array}\right] .
$$

The elements involving $\frac{1}{12}$ derive from the definition of the average real interest rate. The average nominal interest rate is given by

$$
\begin{aligned}
i_{a v, t}= & \frac{1}{12}\left(i_{1, t}+i_{2, t}+\ldots+i_{12, t}\right) \\
= & \frac{1}{12}\left(\theta_{1, t}+i_{t}+\tau_{2}+\theta_{2, t}+\frac{1}{2}\left[i_{t}+E_{t} i_{t+1}\right]+\ldots+\tau_{12}+\theta_{12, t}+\frac{1}{12}\left[i_{t}+\sum_{k=1}^{11} E_{t} i_{t+k}\right]\right) \\
= & \frac{1}{12}\left(\theta_{1}+i_{t}-c E_{t} y_{t+1}+\varepsilon_{1, t}\right. \\
& +\tau_{2}+\theta_{2}+\frac{1}{2}\left[i_{t}+E_{t} i_{t+1}-c E_{t} y_{t+1}-c E_{t} y_{t+2}\right]+\varepsilon_{2, t} \\
& +\ldots \\
& \left.+\tau_{12}+\theta_{12}+\frac{1}{12}\left[i_{t}+\sum_{k=1}^{11} E_{t} i_{t+k}-c E_{t} y_{t+1}-\sum_{k=2}^{12} c E_{t} y_{t+k}\right]+\varepsilon_{12, t}\right)
\end{aligned}
$$




$$
\begin{aligned}
= & \frac{1}{12}\left(\theta_{1}+i_{t}-c E_{t} y_{t+1}+\varepsilon_{1, t}\right. \\
& +\tau_{2}+\theta_{2}+\frac{1}{2}\left[i_{t}-c E_{t} y_{t+1}+f_{i} \sum_{k=1}^{1} E_{t} \widetilde{X}_{t+k}-c f_{y} \sum_{k=2}^{2} E_{t} \widetilde{X}_{t+k}\right]+\varepsilon_{2, t} \\
& +\ldots \\
& \left.+\tau_{12}+\theta_{12}+\frac{1}{12}\left[i_{t}-c E_{t} y_{t+1}+f_{i} \sum_{k=1}^{11} E_{t} \widetilde{X}_{t+k}-c f_{y} \sum_{k=2}^{12} E_{t} \widetilde{X}_{t+k}\right]+\varepsilon_{12, t}\right) \\
= & \frac{1}{12}\left(\theta_{1}+\varepsilon_{1, t}\right)+\frac{1}{12} \sum_{j=1}^{12} \frac{1}{j}\left[i_{t}-c E_{t} y_{t+1}\right] \\
& +\frac{1}{12} \sum_{j=2}^{12}\left\{\tau_{j}+\theta_{j}+\varepsilon_{j, t}+\frac{1}{j}\left[f_{i} \sum_{k=1}^{j-1} M^{k} \widetilde{X}_{t}-c f_{y} \sum_{k=2}^{j} M^{k} \widetilde{X}_{t}\right]\right\}
\end{aligned}
$$

For the fourth equality, we note that the expected future values of $i_{t}, y_{t}$ and $\pi_{t}$ are driven by optimal policy. In particular, we define the inflation rate resulting from the optimisation as

$$
\pi_{t}=f_{\pi} \widetilde{X}_{t} .
$$

Computing $\pi_{a v, t}$ along the same lines as the average nominal interest rate above, we obtain

$$
\begin{aligned}
E_{t} \pi_{a v, t+1} & =\frac{1}{12} E_{t}\left(\pi_{1, t+1}+\pi_{2, t+1}+\ldots+\pi_{12, t+1}\right) \\
& =\frac{1}{12} E_{t}\left(\pi_{t+1}+\frac{1}{2}\left[\pi_{t+1}+\pi_{t+2}\right]+\ldots+\frac{1}{12} \sum_{k=1}^{12} \pi_{t+k}\right) \\
& =\frac{1}{12} f_{\pi} \sum_{j=1}^{12} \frac{1}{j}\left[\sum_{k=1}^{j} M^{k} \widetilde{X}_{t}\right]
\end{aligned}
$$

Thus, the average real interest rate is

$$
\begin{aligned}
i_{a v, t}-E_{t} \pi_{a v, t+1}= & \frac{1}{12}\left(\theta_{1}+\varepsilon_{1, t}\right)+\frac{1}{12} \sum_{j=1}^{12} \frac{1}{j}\left[i_{t}-c E_{t} y_{t+1}-E_{t} \pi_{t+1}\right] \\
& +\frac{1}{12} \sum_{j=2}^{12}\left\{\tau_{j}+\theta_{j}+\varepsilon_{j, t}+\frac{1}{j}\left[f_{i} \sum_{k=1}^{j-1} M^{k} \widetilde{X}_{t}-\left(c f_{y}+f_{\pi}\right) \sum_{k=2}^{j} M^{k} \widetilde{X}_{t}\right]\right\} .
\end{aligned}
$$




\section{References}

[1] Amisano, Gianni and Oreste Tristani (2008), A DSGE model of the term structure with regime shifts, mimeo.

[2] Ang, Andrew and Monika Piazzesi (2003), A no-arbitrage vector auto-regression of term structure dynamics with macroeconomic and latent variables, Journal of Monetary Economics 50(4), 745-787.

[3] Atkeson, Andrew and Patrick J. Kehoe (2008), On the need for a new approach to analyzing monetary policy, Federal Reserve Bank of Minneapolis Staff Report 412.

[4] Bernanke, Ben S. (2005), Implementing monetary policy, speech available at http://www.federalreserve.gov/boarddocs/speeches/2005/20050330/default.htm

[5] Bindseil, Ulrich (2004), Monetary policy implementation: Theory, past and present, Oxford University Press, Oxford.

[6] Borio, Claudio (1997), Monetary policy operating procedures in industrial countries, BIS working paper 40 .

[7] Borio, Claudio and William Nelson (2008), Monetary operation and the financial turmoil, BIS Quarterly Review, March, 31-46.

[8] Campbell, John Y., Andrew W. Lo and A. Craig MacKinlay (1997), The econometrics of financial markets, Princeton University Press, Princeton NJ.

[9] Cúrdia, Vasco and Michael Woodford (2009), Credit frictions and monetary policy, mimeo.

[10] Dennis, Richard and Ulf Söderström (2006), How important is precommitment for monetary policy? Journal of Money, Credit, and Banking 38(4), 847-872.

[11] Dewachter, Hans and Marco Lyrio (2003), Macro factors and the term structure of interest rates, Journal of Money, Credit and Banking 38(1), 119-140.

[12] Eijffinger, Sylvester, Eric Schaling and Willem Verhagen (2000), The term structure of interest rates and inflation forecast targeting, CEPR Discussion Paper 2375. 
[13] Ellis, Lucy and Philip Lowe (1997), The smoothing of official interest rates, in: Monetary policy and inflation targeting: Proceedings of a conference, Philip Lowe (ed.), Reserve Bank of Australia, Sydney.

[14] Emiris, Marina (2006), The term structure of interest rates in a DSGE model, National Bank of Belgium Working Paper Research 88.

[15] English, William B., William R. Nelson and Brian P. Sack (2002), Interpreting the significance of the lagged interest rate in estimated monetary policy rules, Contributions to Macroeconomics 3(1), Article 5.

[16] Fama, Eugene F. and Kenneth R. French (1989), Business conditions and expected returns on stocks and bonds, Journal of Financial Economics 25, 23-49.

[17] Fendel, Ralf (2009), Note on Taylor rules and the term structure, Applied Economics Letters 16(11), 1097-1101.

[18] Flemming, John S. (1990), Three points on the yield curve, Greek Economic Review 12 (supplement), 119-132.

[19] Gerlach-Kristen, Petra and Barbara Rudolf (2010), Financial shocks and the maturity of the monetary policy rate, Economics Letters 107(3), 333-337.

[20] Goodfriend, Marvin and Bennett T. McCallum (2007), Banking and interest rates in monetary policy analysis: A quantitative explorations, Journal of Monetary Economics 54, 14801507.

[21] Goodhart, Charles (1999), Central bankers and uncertainty, Bank of England Quarterly Bulletin, February. Reprint of a speech at the annual Keynes lecture, British Academy, London, October 1998, 102-114.

[22] Hördahl, Peter, Oreste Tristani and David Vestin (2006), A joint econometric model of macroeconomics and term-structure dynamics, Journal of Econometrics 131, 405-444.

[23] Jordan, Thomas J. and Peter Kugler (2004), Implementing Swiss monetary policy: Steering the 3M-Libor with repo transactions, Swiss Journal of Economics and Statistics 140(3), 381393. 
[24] Jordan, Thomas J., Angelo Ranaldo and Paul Söderlind (2009), The implementation of SNB monetary policy, mimeo.

[25] Kozicki, Sharon and P.A. Tinsley (2008), Term structure transmission of monetary policy, North American Journal of Finance and Economics 19(1), 71-92.

[26] Kulish, Mariano (2007), Should monetary policy use long-term rates? B.E. Journal of Macroeconomics, Advances 7(1), Article 15.

[27] Lansing, Kevin J. and Bharat Trehan (2003), Forward-looking behavior and optimal discretionary monetary policy, Economics Letters 81(2), 249-256.

[28] Marcet, Albert and Ramon Marimon (1998), Recursive contracts, mimeo.

[29] Martin, Christopher and Costas Milas (2008), The sub-prime crisis and UK monetary policy, mimeo.

[30] McGough, Bruce, Glenn Rudebusch and John C. Williams (2005), Using a long-term interest rates as the monetary policy instrument, Journal of Monetary Economics 52, 855 879 .

[31] Michaud, François-Louis and Christian Upper (2008), What drives interbank rates? Evidence from the libor panel, BIS Quarterly Review, March, 47-58.

[32] Piazzesi, Monika and Eric Swanson (2006), Futures prices as risk-adjusted forecasts of monetary policy, Federal Reserve Bank of San Francisco Working Paper 2006-23.

[33] Rudebusch, Glenn D. (2002), Term structure evidence on interest-rate smoothing and monetary policy inertia, Journal of Monetary Economics 49(6), 1161-1187.

[34] Rudebusch, Glenn D., Brian P. Sack and Eric T. Swanson (2007), Macroeconomic implications of changes in the term premium, Federal Reserve Bank of St. Louis Review 89(4), 241-269.

[35] Söderlind, Paul (1999), Solution and estimation of RE macromodels with optimal policy, European Economic Review 43, 813-823.

[36] Svensson, Lars E.O. (1993), Term, inflation, and foreign exchange risk premia: A unified treatment, NBER Working Paper 4544. 
[37] Svensson, Lars E.O. (2000), Open-economy inflation targeting, Journal of International Economics 50, 155-183.

[38] Svensson, Lars E.O. and Noah Williams (2007), Monetary policy with model uncertainty: Distribution forecast targeting, mimeo.

[39] Svensson, Lars E.O. and Michael Woodford (2005), Implementing optimal policy through inflation-forecast targeting, in: Bernanke, Ben S. and Michael Woodford (eds), Inflation targeting, University of Chicago Press.

[40] Taylor, John B. (2008), The costs and benefits of deviating from the systematic component of monetary policy, speech available at frbsf.org/economics/conferences/0802/taylor.pdf

[41] Woodford, Michael (1999), Optimal monetary policy inertia, NBER Working Paper No 7261.

[42] Woodford, Michael (2003), Interest and prices: Foundations of a theory of monetary policy, Princeton University Press. 


\section{Swiss National Bank Working Papers published since 2004:}

2004-1 Samuel Reynard: Financial Market Participation and the Apparent Instability of Money Demand

2004-2 Urs W. Birchler and Diana Hancock: What Does the Yield on Subordinated Bank Debt Measure?

2005-1 Hasan Bakhshi, Hashmat Khan and Barbara Rudolf: The Phillips curve under state-dependent pricing

2005-2 Andreas M. Fischer: On the Inadequacy of Newswire Reports for Empirical Research on Foreign Exchange Interventions

2006-1 Andreas M. Fischer: Measuring Income Elasticity for Swiss Money Demand: What do the Cantons say about Financial Innovation?

2006-2 Charlotte Christiansen and Angelo Ranaldo: Realized Bond-Stock Correlation: Macroeconomic Announcement Effects

2006-3 Martin Brown and Christian Zehnder: Credit Reporting, Relationship Banking, and Loan Repayment

2006-4 Hansjörg Lehmann and Michael Manz: The Exposure of Swiss Banks to Macroeconomic Shocks - an Empirical Investigation

2006-5 Katrin Assenmacher-Wesche and Stefan Gerlach: Money Growth, Output Gaps and Inflation at Low and High Frequency: Spectral Estimates for Switzerland

2006-6 Marlene Amstad and Andreas M. Fischer: Time-Varying Pass-Through from Import Prices to Consumer Prices: Evidence from an Event Study with Real-Time Data

2006-7 Samuel Reynard: Money and the Great Disinflation

2006-8 Urs W. Birchler and Matteo Facchinetti: Can bank supervisors rely on market data? A critical assessment from a Swiss perspective

2006-9 Petra Gerlach-Kristen: A Two-Pillar Phillips Curve for Switzerland

2006-10 Kevin J. Fox and Mathias Zurlinden: On Understanding Sources of Growth and Output Gaps for Switzerland

2006-11 Angelo Ranaldo: Intraday Market Dynamics Around Public Information Arrivals

2007-1 Andreas M. Fischer, Gulzina Isakova and Ulan Termechikov: Do FX traders in Bishkek have similar perceptions to their London colleagues? Survey evidence of market practitioners' views 
2007-2 Ibrahim Chowdhury and Andreas Schabert: Federal Reserve Policy viewed through a Money Supply Lens

2007-3 Angelo Ranaldo: Segmentation and Time-of-Day Patterns in Foreign Exchange Markets

2007-4 Jürg M. Blum: Why `Basel II’ May Need a Leverage Ratio Restriction

2007-5 Samuel Reynard: Maintaining Low Inflation: Money, Interest Rates, and Policy Stance

2007-6 Rina Rosenblatt-Wisch: Loss Aversion in Aggregate Macroeconomic Time Series

2007-7 Martin Brown, Maria Rueda Maurer, Tamara Pak and Nurlanbek Tynaev: Banking Sector Reform and Interest Rates in Transition Economies: Bank-Level Evidence from Kyrgyzstan

2007-8 Hans-Jürg Büttler: An Orthogonal Polynomial Approach to Estimate the Term Structure of Interest Rates

2007-9 Raphael Auer: The Colonial Origins Of Comparative Development: Comment. A Solution to the Settler Mortality Debate

2007-10 Franziska Bignasca and Enzo Rossi: Applying the Hirose-Kamada filter to Swiss data: Output gap and exchange rate pass-through estimates

2007-11 Angelo Ranaldo and Enzo Rossi: The reaction of asset markets to Swiss National Bank communication

2007-12 Lukas Burkhard and Andreas M. Fischer: Communicating Policy Options at the Zero Bound

2007-13 Katrin Assenmacher-Wesche, Stefan Gerlach, and Toshitaka Sekine: Monetary Factors and Inflation in Japan

2007-14 Jean-Marc Natal and Nicolas Stoffels: Globalization, markups and the natural rate of interest

2007-15 Martin Brown, Tullio Jappelli and Marco Pagano: Information Sharing and Credit: Firm-Level Evidence from Transition Countries

2007-16 Andreas M. Fischer, Matthias Lutz and Manuel Wälti: Who Prices Locally? Survey Evidence of Swiss Exporters

2007-17 Angelo Ranaldo and Paul Söderlind: Safe Haven Currencies 
2008-1 Martin Brown and Christian Zehnder: The Emergence of Information Sharing in Credit Markets

2008-2 Yvan Lengwiler and Carlos Lenz: Intelligible Factors for the Yield Curve

2008-3 Katrin Assenmacher-Wesche and M. Hashem Pesaran: Forecasting the Swiss Economy Using VECX* Models: An Exercise in Forecast Combination Across Models and Observation Windows

2008-4 Maria Clara Rueda Maurer: Foreign bank entry, institutional development and credit access: firm-level evidence from 22 transition countries

2008-5 Marlene Amstad and Andreas M. Fischer: Are Weekly Inflation Forecasts Informative?

2008-6 Raphael Auer and Thomas Chaney: Cost Pass Through in a Competitive Model of Pricing-to-Market

2008-7 Martin Brown, Armin Falk and Ernst Fehr: Competition and Relational Contracts: The Role of Unemployment as a Disciplinary Device

2008-8 Raphael Auer: The Colonial and Geographic Origins of Comparative Development

2008-9 Andreas M. Fischer and Angelo Ranaldo: Does F0MC News Increase Global FX Trading?

2008-10 Charlotte Christiansen and Angelo Ranaldo: Extreme Coexceedances in New EU Member States' Stock Markets

2008-11 Barbara Rudolf and Mathias Zurlinden: Measuring capital stocks and capital services in Switzerland

2008-12 Philip Sauré: How to Use Industrial Policy to Sustain Trade Agreements

2008-13 Thomas Bolli and Mathias Zurlinden: Measuring growth of labour quality and the quality-adjusted unemployment rate in Switzerland

2008-14 Samuel Reynard: What Drives the Swiss Franc?

2008-15 Daniel Kaufmann: Price-Setting Behaviour in Switzerland - Evidence from CPI Micro Data

2008-16 Katrin Assenmacher-Wesche and Stefan Gerlach: Financial Structure and the Impact of Monetary Policy on Asset Prices

2008-17 Ernst Fehr, Martin Brown and Christian Zehnder: On Reputation: A Microfoundation of Contract Enforcement and Price Rigidity 
2008-18 Raphael Auer and Andreas M. Fischer: The Effect of Low-Wage Import Competition on U.S. Inflationary Pressure

2008-19 Christian Beer, Steven Ongena and Marcel Peter: Borrowing in Foreign Currency: Austrian Households as Carry Traders

2009-1 Thomas Bolli and Mathias Zurlinden: Measurement of labor quality growth caused by unobservable characteristics

2009-2 Martin Brown, Steven Ongena and Pinar Yeșin: Foreign Currency Borrowing by Small Firms

2009-3 Matteo Bonato, Massimiliano Caporin and Angelo Ranaldo: Forecasting realized (co)variances with a block structure Wishart autoregressive model

2009-4 Paul Söderlind: Inflation Risk Premia and Survey Evidence on Macroeconomic Uncertainty

2009-5 Christian Hott: Explaining House Price Fluctuations

2009-6 Sarah M. Lein and Eva Köberl: Capacity Utilisation, Constraints and Price Adjustments under the Microscope

2009-7 Philipp Haene and Andy Sturm: Optimal Central Counterparty Risk Management

2009-8 Christian Hott: Banks and Real Estate Prices

2009-9 Terhi Jokipii and Alistair Milne: Bank Capital Buffer and Risk Adjustment Decisions

2009-10 Philip Sauré: Bounded Love of Variety and Patterns of Trade

2009-11 Nicole Allenspach: Banking and Transparency: Is More Information Always Better?

2009-12 Philip Sauré and Hosny Zoabi: Effects of Trade on Female Labor Force Participation

2009-13 Barbara Rudolf and Mathias Zurlinden: Productivity and economic growth in Switzerland 1991-2005

2009-14 Sébastien Kraenzlin and Martin Schlegel: Bidding Behavior in the SNB's Repo Auctions

2009-15 Martin Schlegel and Sébastien Kraenzlin: Demand for Reserves and the Central Bank's Management of Interest Rates

2009-16 Carlos Lenz and Marcel Savioz: Monetary determinants of the Swiss franc 
2010-1 Charlotte Christiansen, Angelo Ranaldo and Paul Söderlind: The Time-Varying Systematic Risk of Carry Trade Strategies

2010-2 Daniel Kaufmann: The Timing of Price Changes and the Role of Heterogeneity

2010-3 Loriano Mancini, Angelo Ranaldo and Jan Wrampelmeyer: Liquidity in the Foreign Exchange Market: Measurement, Commonality, and Risk Premiums

2010-4 Samuel Reynard and Andreas Schabert: Modeling Monetary Policy

2010-5 Pierre Monnin and Terhi Jokipii: The Impact of Banking Sector Stability on the Real Economy

2010-6 Sébastien Kraenzlin and Thomas Nellen: Daytime is money

2010-7 Philip Sauré: Overreporting Oil Reserves

2010-8 Elizabeth Steiner: Estimating a stock-flow model for the Swiss housing market

2010-9 Martin Brown, Steven Ongena, Alexander Popov, and Pinar Yesin: Who Needs Credit and Who Gets Credit in Eastern Europe?

2010-10 Jean-Pierre Danthine and André Kurmann: The Business Cycle Implications of Reciprocity in Labor Relations

2010-11 Thomas Nitschka: Momentum in stock market returns: Implications for risk premia on foreign currencies

2010-12 Petra Gerlach-Kristen and Barbara Rudolf: Macroeconomic and interest rate volatility under alternative monetary operating procedures 
Swiss National Bank Working Papers are also available at www.snb.ch, section Publications/Research Subscriptions or individual issues can be ordered at Swiss National Bank, Fraumünsterstrasse 8, CH-8022 Zurich, fax+41 4463181 14, E-mail library@snb.ch 